\title{
The Processing of Calcium Rich Agricultural and Industrial Waste for Recovery of Calcium Carbonate and Calcium Oxide and Their Application for Environmental Cleanup: A Review
}

\author{
Virendra Kumar Yadav ${ }^{1, *}$, Krishna Kumar Yadav ${ }^{2,3, *}$, Marina M. S. Cabral-Pinto ${ }^{4, *}{ }^{\mathbb{C}}$, Nisha Choudhary ${ }^{5}$, \\ Govindhan Gnanamoorthy ${ }^{6}\left(\right.$ ) , Vineet Tirth ${ }^{7,8}{ }^{\oplus}$, Shiv Prasad ${ }^{9}$, Afzal Husain Khan ${ }^{10}{ }^{\circ}$, Saiful Islam ${ }^{11}$ and \\ Nadeem A. Khan ${ }^{12}$ (1)
}

check for updates

Citation: Yadav, V.K.; Yadav, K.K.; Cabral-Pinto, M.M.S.; Choudhary, N.; Gnanamoorthy, G.; Tirth, V.; Prasad, S.; Khan, A.H.; Islam, S.; Khan, N.A. The Processing of Calcium Rich Agricultural and Industrial Waste for Recovery of Calcium Carbonate and Calcium Oxide and Their Application for Environmental Cleanup: A Review. Appl. Sci. 2021, 11, 4212. https://doi.org/10.3390/app11094212

Academic Editors: Raffaele Marotta and Bart Van der Bruggen

Received: 26 January 2021

Accepted: 9 March 2021

Published: 6 May 2021

Publisher's Note: MDPI stays neutral with regard to jurisdictional claims in published maps and institutional affiliations.

Copyright: (c) 2021 by the authors. Licensee MDPI, Basel, Switzerland. This article is an open access article distributed under the terms and conditions of the Creative Commons Attribution (CC BY) license (https:/ / creativecommons.org/licenses/by/ $4.0 /)$.
1 School of Life Sciences, Jaipur National University, Jaipur 302017, Rajasthan, India

2 Institute of Environment and Development Studies, Bundelkhand University, Kanpur Road, Jhansi 284128, UP, India

3 Faculty of Science and Technology, Madhyanchal Professional University Ratibad, Bhopal 462044, M.P, India

4 Geobiotec Research Centre, Department of Geoscience, University of Aveiro, 3810-193 Aveiro, Portugal

5 School of Nano Sciences, Central University of Gujarat, Gandhinagar 382030, Gujarat, India; nishanaseer03@gmail.com

6 Department of Chemistry, Guindy Campus, University of Madras, Chennai 600025, Tamil Nadu, India; gnanadrdo@gmail.com

7 Mechanical Engineering Department, College of Engineering, King Khalid University, Abha 61411, Saudi Arabia; vtirth@kku.edu.sa or v.tirth@gmail.com

8 Research Center for Advanced Materials Science (RCAMS), King Khalid University, Guraiger, Abha 61413, Asir, Saudi Arabia

9 Centre for Environment Science and Climate Resilient Agriculture, Indian Agricultural Research Institute, New Delhi 110012, India; shiv_drprasad@yahoo.co.in

10 Civil Engineering Department, College of Engineering, Jazan University, Jazan 114, Saudi Arabia; ahkhan@jazanu.edu.sa

11 Civil Engineering Department, College of Engineering, King Khalid University, Abha 61411, Asir, Saudi Arabia; sfakrul@kku.edu.sa

12 Department of Civil Engineering, Jamia Millia Islamia, New Delhi 110025, India; er.nadimcivil@gmail.com

* Correspondence: virendra.yadav@jnujaipur.ac.in (V.K.Y.); envirokrishna@gmail.com (K.K.Y.); marinacp@ua.pt (M.M.S.C.-P.)

Abstract: Every year a million tonnes of calcium rich agro and industrial waste are generated around the whole globe. These calcium rich waste like finger citron, shells of cockle, mussel, oysters etc., and egg shell are biological sources which have various organic compounds. The inorganic calcium rich waste includes gypsum, dolomite, sludge etc., which are produced in surplus amount globally. Most of these by-products are mainly dumped, while few are used for land-filling purposes which leads to the pollution. These agro and industrial by-products could be processed for the recovery of calcium carbonate and calcium oxide particles by physical and chemical method. The recovery of calcium carbonate and calcium oxide particles from such by products make them biocompatible. Moreover, the products are economical due to their synthesis from waste materials. Here, in this current review work we have emphasized on the all the calcium rich agro industries and industrial by products, especially their processing by various approaches. Further, we have also focused on the properties and application of such calcium carbonate and oxide particles for the remediation of organic and inorganic pollutants from the environments. The recovery of such particles from these byproducts is considered not only economical and eco-friendly but it also minimizes the pollution present in the form of solid waste.

Keywords: calcium carbonate nanoparticles; calcium oxide nanoparticles; incense sticks ash; fly ash; sludge; eggshell 


\section{Introduction}

Every day we encounter various agricultural and industrial products for our easiness and requirements. Out of these products, various products have different origin and chemical values. Agricultural industries is the backbone of any country, due to its importance in any countries GDP [1,2]. In addition, there are several other industries like steel, mineral processing, paper, and pulp industries etc., which also play a major role in a human's life. Both these types of industries fulfills our daily requirements. The progress of any country is measured by the growth of their industries. However, one major drawback with such industries is that they produces million tonnes of by-products every day throughout the whole world [3]. The accumulation of byproducts from such industries leads to the various forms of pollution due to the presence of toxic constituents [4]. The agricultural industry waste like citrus peel waste, paper and pulp waste contain moisture and attracts the flies and bugs leading to the health related issues [5]. While, the industrial waste like fly ash by-products of thermal power plants [6], gypsum waste from medical and hospitals leads [7] to the accumulation of hazardous by products due to the presence of heavy metals, etc. Here, we have focused on the recycling of calcium rich agricultural and industrial waste for the synthesis of value added minerals like calcium carbonate and calcium oxide. Both of these minerals are biocompatible, non-toxic, and used every day in oils, plastic, imaging purposes, alloys and catalyst [8], environment-friendly items [9], calcium-enriched food [10,11], drug delivery [12,13], cosmetics and pharmaceuticals [10], templates for microcapsules [14,15], and bone filling material [12]. Currently the commercial production of $\mathrm{CaCO}_{3}$, calcium oxide and other derivatives of calcium is mainly carried out by using quick lime as a precursor material. Most of these quick limes are obtained by the mining which is laborious, and energy intensive process hence the final product is comparatively expensive [16]. So, there is an immediate need of a sustainable, economical, and an alternative source of calcium rich materials. There are several materials in our environment which are rich source of $\mathrm{CaCO}_{3}$ like limestone, marbles, gypsum waste, cockle shell, eggshell, incense sticks, and high calcium fly ash (class $\mathrm{C}$ ) and hard shell of shellfish, i.e., marine organisms (snails, oysters, shrimps, and pearls) [17-19].

Calcium carbonate $\left(\mathrm{CaCO}_{3}\right)$ is a white color powder and water insoluble-inorganic biomaterials [18]. In nature, $\mathrm{CaCO}_{3}$ is present in three different forms, i.e., calcite, aragonite, and vaterite [20]. Due to its biocompatible nature, aragonite receives extensive research attention worldwide. Among all these three polymorphs, calcite is thermodynamically most stable [21]. Calcite is the most stable polymorph of $\mathrm{CaCO}_{3}$ [22], but aragonite has higher density and hardness from the other two polymorphs of calcium carbonate, which makes them very suitable material in plastic, paper, glass, fiber, and other industry [23]. A study reported the needle-shaped aragonite synthesis under a controlled injection of $\mathrm{CO}_{2}$ in $\mathrm{Ca}(\mathrm{OH})_{2}$ slurry suspended $\mathrm{MgCl}_{2}$ aqueous solution. These investigators also reported that the residual $\mathrm{MgCl}_{2}$ solution from the previous step, could be reused for the synthesis of aragonite synthesis as both $\mathrm{Mg}^{2+}$ and $\mathrm{Ca}^{2+}$ ions are not incorporated into the aragonite crystals. At the time of formation of aragonite, $\mathrm{Mg}^{2+}$ ions acts as an impurity, which promotes the formation of aragonite crystals along with simultaneous impeding the nucleation and growth of calcite crystal. While another study carried by a group of investigators reported that the more the concentration of $\mathrm{Ca}^{2+}$ ions in the solution, the higher the possibility of formation of aragonite crystals will be [24-26]. To rationalize this cognition, numerous theories and empirical relationships have been provided such as alteration of surface charge, inhibition of calcite nucleation, and calcite poisoning model [21].

As an adsorbent calcium carbonate and calcium oxide particles have several advantages over the conventional adsorbents due to their low cost, biocompatibility, biodegradability, easy availability, non-toxic nature, and diverse polymorphs [27]. Due to all these properties calcium carbonate and calcium oxide particles have gained a huge attention in the field of environmental remediation especially for wastewater treatment. These calcium based minerals remediate the inorganic and organic pollutants from the environment by 
the adsorption process. The low cost and eco-friendly nature of calcium based minerals reduce the expenditure of the whole adsorption process.

\section{Types and Properties of Calcium Carbonate Particles}

In general, there are two sources of $\mathrm{CaCO}_{3}$, one is ground calcium carbonate (GCC) and another one is precipitated calcium carbonate (PCC) [8], chalk, or marble. While the PCC is present as crystals and exists in three polymorphs, i.e., calcite, aragonite, and vaterite. Though they have several identical properties still they vary in the following manner as shown in Table 1. While all the PCC types of polymorphs are differentiated above in the Table 2.

Table 1. Differences between ground and precipitated calcium carbonate particles.

\begin{tabular}{|c|c|c|c|}
\hline S. No. & Ground Calcium Carbonate & Precipitated Calcium Carbonate & References \\
\hline 1. Source & Extracted from earth & $\begin{array}{l}\text { Present as crystals in calcite (rhombohedral), aragonite } \\
\text { (orthorhombic), and vaterite (hexagonal) forms }\end{array}$ & [28] \\
\hline 2. Examples & Examples: chalks, marble & - & \\
\hline 3. Processing & $\begin{array}{l}\text { Grinding is required either in } \\
\text { wet or dry conditions. }\end{array}$ & - & \\
\hline 4. Available in market & - & Commercial PCC was produced in 1841. & \\
\hline 5. Methods for synthesis & Thermolysis & $\begin{array}{l}\text { Three common processes for the production of } \\
\text { synthetic PCC(1) lime soda process(2) calcium } \\
\text { chloride process( } 3 \text { ) the carbonation process }\end{array}$ & [29] \\
\hline
\end{tabular}

Table 2. Differences between different types of calcium carbonate nanoparticles polymorphs.

\begin{tabular}{llll}
\hline \multicolumn{1}{c}{ S. No. } & \multicolumn{1}{c}{ Calcite } & \multicolumn{1}{c}{ Aragonite } & \multicolumn{1}{c}{ Vaterite } \\
\hline 1. ThermalStability & $\begin{array}{l}\text { Thermodynamically } \\
\text { most stable }\end{array}$ & Moderately stable & Least stable polymorph \\
\hline 2. Solubility & - & $\begin{array}{l}\text { More soluble and denser } \\
\text { than calcite }\end{array}$ & - \\
\hline 3. Structure & Exists as a trigonal \\
crystalline form in nature & $\begin{array}{l}\text { Forms needle-like } \\
\text { orthorhombic crystals and } \\
\text { formed at higher } \\
\text { temperature and pressure }\end{array}$ & $\begin{array}{l}\text { Hexagonal structure and } \\
\text { rarely seen in the } \\
\text { natural mineral }\end{array}$ \\
\hline 4. Stability & - & $\begin{array}{l}\text { Metastable and slowly gets } \\
\text { converted to calcite }\end{array}$ & [23] \\
\hline $\begin{array}{l}\text { 5. Interaction with water } \\
\text { and reorganization }\end{array}$ & - & - & $\begin{array}{l}\text { Vaterite when exposed to } \\
\mathrm{H}_{2} \text { O, slowly dissolves and } \\
\text { recrystallizes to a stable form }\end{array}$ \\
\hline 6. Porosity, surface area & - & - & $\begin{array}{l}\text { Large porosity and large } \\
\text { surface area }\end{array}$ \\
\hline 7. Disintegrity & - & Biocompatible properties & $\begin{array}{l}\text { Rapid disintegration under } \\
\text { relatively mild conditions }\end{array}$ \\
\hline 8. Biocompatibility & - & &
\end{tabular}

Calcium based particles has drawn their attention towards different scientific filed in the last decade due to their diversity in morphology, biocompatible in nature, economical, and non-toxic effect on the environment [27]. Since the calcium is already present in our body, microbes, plants, etc., it does not have a detrimental effect on any of these species, so it is considered as superior particles, in comparison to other metal oxide particles. Such as, $\mathrm{ZnO}, \mathrm{TiO}_{2}$, etc., are photo catalytic in nature, whereas $\mathrm{CuO}$, CoNPs, etc., are toxic due to their heavy metal nature. These metals oxide particles persists in nature for much longer 
time and may show, bio magnification in the higher animals in the food chain. Whereas calcium is already present in almost most of the organisms, so there is already degradation mechanism present in the organism for calcium based particles. The types of calcium carbonate particles are based on their morphology. Calcium carbonate particles (CCPs) are white color powder, insoluble in water but soluble in $\mathrm{HCl}$, biocompatible, $\mathrm{pH}$ sensitive, biodegradable, abundant in nature, economically viable, and exhibit polymorphism [27]. CCPs aggregate easily during the process of preparation and disposal [30].

\section{Different Sources of Calcium Carbonate Particles (CCPs)}

In nature, there are numerous calcium-rich particles which can be used as a source of CCPs synthesis. For instance, there are biological materials like cockle and shellfish. All these sea animals have a hard covering on their surface, which is meant for protection, safety from the wear and tear, and prey. These animals have very soft internal organs, so a hard-calcareous covering is required. So, their shells can be used for the extraction of CCPs by various means of processing. Most of these sea animals lose their hard covering after their death and there is the mineralization of calcium into the seawater. In addition, there are several domestic and industrial waste which have also higher content of calcium. For instance, eggshell and incense sticks ash from the domestic waste. While high Ca fly ash, gypsum waste [30], calcium sulfide waste [31], sludge is industrial waste which is also rich sources of calcium. All these materials are discussed below in detail by emphasizing the steps for the recovery of $\mathrm{CaO}$ NPs. Most of these calcium-rich materials are waste so the recovery of CCPs and calcium derivatives from these materials are considered economical and environment-friendly.

\subsection{Domestic Waste}

The waste which is generated in the houses especially in the kitchen is called household waste, domestic waste, or kitchen waste [32]. Among all the high calcium-containing waste, incense sticks ashes are considered as most orphan and least considered; though it did produce about 1-2 MTs in India, and this figure would rise drastically if the major incense sticks consuming countries like China, USA, and South Asian countries were also considered. South Asian countries alone generates tonnes of ISA at religious places [33]. Though it is also produced in a small amount at various houses of South Asian counties [34]. Several investigators have classified the eggshell in household waste. However, the utilization of eggs at home is lesser than the industries so few investigators have categorized them into industrial waste. Therefore, here we will consider only incense sticks ash waste as a source of CCNPs.

\subsection{Incense Sticks Ash}

Incense sticks ash (ISA) is one of the major household wastes in South-east Asian countries like China, Taiwan, Thailand, and India. Incense sticks are majorly used in the temples, churches, mosques, houses, and other religious places. In Taiwan alone, a total of 3580 tons of incense sticks are consumed yearly in temples alone and if household burning is also considered then this value may reach to double or triple and may indicate an environment hazardous situation $[33,35]$. The size and composition of an incense sticks varies from one country and one religion to another. Currently, most of the countries, including India, do not have exact data on the incense sticks ash production. The only information we have regarding this is that: Brazil, China, U.S.A and India, are the leading manufacturer of incense sticks. India is the third largest manufacturers of incense sticks and fourth largest consumer of incense sticks. Along with USA, India also exports most of the incense sticks to Gulf countries, and Mexico. In India, the average size of an incense sticks is $8-9$ inches and width is about $1-3 \mathrm{~mm}$. Generally, Indian markets have two types of incense sticks: one is charcoal, or coal based (black in color), whereas the other one is non charcoal based whose color could be grey, or any other color. The black color incense sticks ashes have ferrous, silica, alumina, carbon, and calcium oxides. Indian incense sticks 
manufactures uses calcium phthalate in order to minimize the smoke released during burning of sticks. So, this is the one of the source of high amount of calcium oxides in the ISA. The ISA have nearly 50-56\% calcium oxides [36]. The composition of incense are herbal and wood powder $21 \%$, fragrant materials $35 \%$, adhesive powder $11 \%$, bamboo stick $33 \%$ by weight $[37,38]$. The complete combustion of a 9 inch and $1-2 \mathrm{~mm}$ incense stick, produces one-third ash by weight while the remaining $60-70 \%$ weight of incense sticks is made up of volatile matters like essential oil, fragrance, and combustible matter. Hazarika et al., 2018 and Yadav et al., 2020, reported that India alone consumes approximately 3-4 million tonnes of incense sticks, while USA was one of the largest importer of incense sticks from India. Based on the above information, we can predict that India alone generates 0.3-0.4 million tonnes of ISA from the various religious places and homes. The same information from other countries would be impossible to estimate as there is hardly any information available from the government or in the literature [36].

The chemical composition of incense sticks ash is given below in Table 3. The X-ray fluorescence analysis reveals that the incense ash has $\mathrm{CaO} 50-55 \%$, Ferrous oxide $\left(\mathrm{Fe}_{2} \mathrm{O}_{3} / \mathrm{Fe}_{3} \mathrm{O}_{4}\right)$ $4-5 \%$, Aluminum oxide $\left(\mathrm{Al}_{2} \mathrm{O}_{3}\right) 4-5 \%$, Silica oxide $15-20 \%$, magnesium oxide $4-5 \%$. In addition, it also has a high amount of alkali oxides, i.e., $\mathrm{Na}_{2} \mathrm{O}, \mathrm{K}_{2} \mathrm{O}$, traces of $\mathrm{TiO}_{2}, \mathrm{CuO}$, and other heavy metals. Figure 1 shows the flowchart of the synthesis of $\mathrm{CaCO}_{3}$ from ISA, while Figure 2 shows field emission scanning electron micrograph (FESEM) of calcium carbonate microparticles from incense sticks ash. Oral and Ercan (2018), also reported the calcium carbonate particles of various sizes synthesized by chemical routes. Out of these cuboidal shaped particles were also observed, by varying the temperature of synthesis [39]. In Figure 1, initially ISA was mixed with distilled water (1:5) to form a slurry. Further with the help of an external magnet, the ferrous particles were separated as ferrous will add impurity in the final calcium carbonate particles. Further, it was dried in an oven at $50{ }^{\circ} \mathrm{C}$, followed by treatment with sulphuric acid at $90^{\circ} \mathrm{C}$ for 90 min to extract alumina along with stirring at $400 \mathrm{rpm}$. Further, after completion of the reaction, mixture was cooled to room temperature (RT), followed by the centrifugation. The obtained residue was washed several times with distilled water, followed by drying in an oven at $60^{\circ} \mathrm{C}$. About $8 \mathrm{~g}$ of residue was treated with $4 \mathrm{M} \mathrm{NaOH}$ at $90^{\circ} \mathrm{C}$ for 90 min along with stirring at $400 \mathrm{rpm}$. Further, the residue was calcinated at $600-700{ }^{\circ} \mathrm{C}$ for $6 \mathrm{~h}$, followed by dilute $\mathrm{HCl}$ treatment in a round bottom (RB) flask, along with stirring at RT. Around $10 \mathrm{~mL}$ aqueous leachate obtained with $\mathrm{HCl}$ treatment was mixed with dropwise methanol in a RB flask at RT. The mixture was centrifuged at $7000 \mathrm{rpm}$ for $10 \mathrm{~min}$, where the residue was discarded while the supernatant was collected. Further, about $10 \mathrm{~mL}$ of supernatant was taken up, to which $2 \%$ solution of sodium bicarbonate was added drop wise along with stirring at RT in a RB flask. The mixture was centrifuged at $7000 \mathrm{rpm}$ for $10 \mathrm{~min}$, supernatant discarded while the precipitate was collected. Finally, it was washed twice each with distilled water and ethanol followed by drying at $60^{\circ} \mathrm{C}$ for overnight.

Table 3. The elemental composition of incense sticks ash by X-ray fluorescence.

\begin{tabular}{ccc}
\hline S. No. & Chemical Elements & Weight (\%) \\
\hline 1. & $\mathrm{CaO}$ & $50-55$ \\
2. & $\mathrm{MgO}$ & $4-5$ \\
3. & $\mathrm{SiO}$ & $15-20$ \\
4. & $\mathrm{Al}_{2} \mathrm{O}_{3}$ & $4-5$ \\
5. & $\mathrm{Fe}_{2} \mathrm{O}_{3} / \mathrm{Fe}_{3} \mathrm{O}_{4}$ & $4-5$ \\
6. & $\mathrm{TiO}_{2}$ & $2-3$ \\
7. & Others $\left(\mathrm{CuO}+\mathrm{Na}_{2} \mathrm{O}+\mathrm{K}_{2} \mathrm{O}\right)$ & $5-10$ \\
\hline
\end{tabular}


Incense sticks ash + DDW

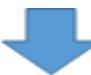

Removal of ferrous fractions using an external magnet

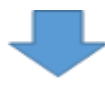

Drying

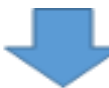

Sulphuric acid treatment

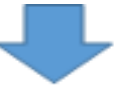

$\mathrm{NaOH}$ treatment

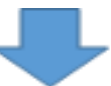

Calcination

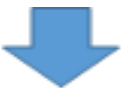

$\mathrm{HCl}$ treatment

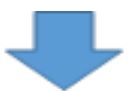

Leachate+ Methanol, Stirring

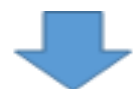

Supernatant+ Na bicarbonate+ stirring

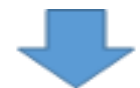

Centrifugation

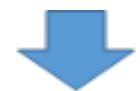

Precipitation

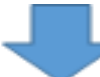

Washing and drying

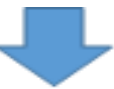

\section{Powder $\mathrm{CaCO}_{3}$}

Figure 1. Flow chart for the separation of calcium carbonate from incense stick ash. 


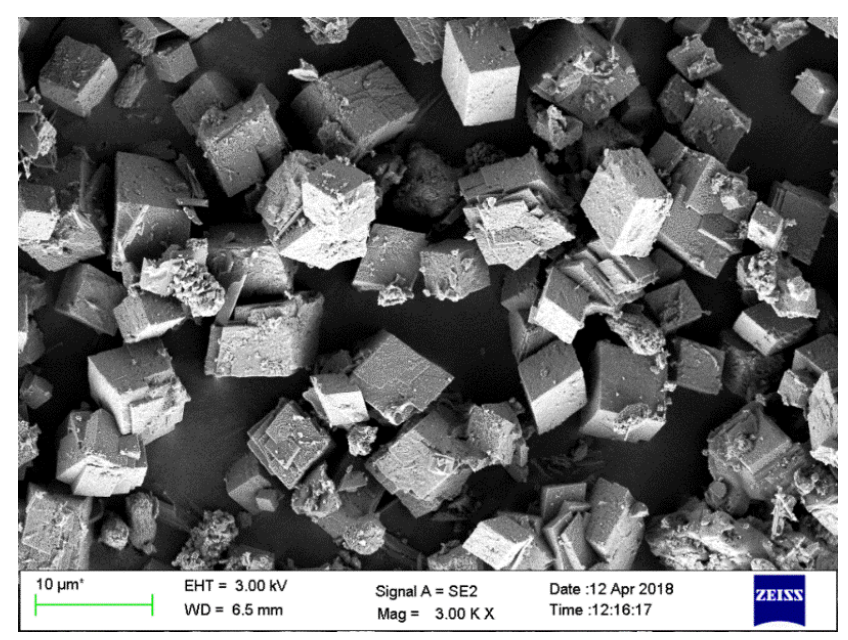

Figure 2. Field emission scanning electron micrograph (FESEM) of the calcite phase of calcium carbonate microparticles from incense sticks ash.

\section{Extraction of Calcium Oxide Particles from Eggshell Waste}

The bioconversion of waste material like eggshell from poultry industries into a valuable material is highly significant for economic development and waste management [40]. The eggshell waste is classified in both industrial wastes as well as in agricultural waste. The utilization of these wastes for the production of valuable materials like fertilizers, feed supplements, adsorbents, and CCNPs not only provides a solution to the disposal of eggshell but also minimizes the pollution in the environment [41,42]. Among all the countries, China, USA, and India is the leading producer of eggs which contributes near about 80 million metric tonnes, where Chinas share is 458, USA's share is 109, and India's share is 95 billion eggs per shell as per the 2017 literature. While in 2018, the global egg production was approximately, 78 million metric tonnes. These 78 million metric tonnes produced about 8.58 million metric tonnes of eggshells which are mainly dumped of as waste, while some parts of the world, it is used as landfills, and for fillers, etc. [43]. The eggshell consists of about $10-11 \%$ weight of the total weight of an egg. Annually around, 250,000 tons of eggshell waste is generated during processing [44]. There are 150,000 tons of chicken eggshell disposed of in landfills every year in the U.S alone. The eggshell comprises about $95 \% \mathrm{CaCO}_{3}$ as calcite and $5 \%$ organic materials such as type $\mathrm{X}$ collagen, sulfated polysaccharides, and other proteins which is provided below in Table 4 [45]. The disposal methods for waste eggshells are $26.6 \%$ as fertilizer, $21.1 \%$ as animal feed ingredients, $26.3 \%$ discarded in municipal dumps, and $15.8 \%$ used in other ways [41]. Habte et al., 2020 reported the synthesis of microsized $(10-30 \mu \mathrm{m})$ aragonite calcium carbonate particles from eggshell waste by carbonation method along with calcination at high temperature.

Table 4. The chemical composition of chicken eggshell.

\begin{tabular}{ccc}
\hline S. No. & Chemical Elements & Concentration $(\mathrm{mg} / \mathrm{L})$ \\
\hline 1. & $\mathrm{Ca}$ & $2296-2304$ \\
2. & $\mathrm{Mg}$ & $849-852$ \\
3. & $\mathrm{Na}$ & $33-35$ \\
4. & $\mathrm{~K}$ & $16-19$ \\
5. & $\mathrm{Fe}$ & $1.01-1.43$ \\
6. & $\mathrm{Zn}$ & $0.95-1.03$ \\
7. & $\mathrm{Cu}$ & $0.062-0.064$ \\
\hline
\end{tabular}

India is also one of the major poultry industry countries which have a poultry population of 489 million, producing 47 billion eggs per year. India ranks third among the highest egg producing countries in the world [46]. The outermost cover of the egg is called 
eggshell whose weight is $10-11 \%$ to that of the total weight of the egg and made up of mainly $\mathrm{CaCO}_{3}(96 \%)$ and trace elements. The chemical composition of eggshell waste is given below in the table. Currently, it is mainly dumped as landfills in most of the developed or developing countries. Disposal of eggshell and the underlying membrane further contributes to environmental pollution [47].

Hassan et al. (2013) reported the synthesis of CCPs from the chicken eggshell waste, which encompasses the following steps cleaning and size reduction of eggshell, followed by surface modification by the sonochemical method for enhanced dispersion $[48,49]$. Hariharan et al. (2014) reported the successful synthesis of calcite NPs from eggshell waste using gelatin $[50,51]$. The calcite polymorph of $\mathrm{CaCO}_{3}$ was synthesized using from chicken eggshells employing gelatin via precipitation method and the confirmation of the nano calcite was done by X-ray powder diffraction (XRD), Fourier-transform infrared spectroscopy (FTIR), UV-Visible (UV-Vis) spectroscopy and scanning electron microscopy (SEM). The identified particles were calcite polymorphs with a particle size of $25 \mathrm{~nm}$. The analysis results confirmed the formation of calcite NPs and the obtained results were compared with $\mathrm{CaCO}_{3}$ synthesis without using gelatin. Render et al. (2016) reported the synthesis of CCPs by using eggshell waste that has been used for enteric drug delivery. The sequential steps involved in the synthesis of CCPs from eggshell was initial cleaning, mechanochemical milling, and Sonochemical irradiation [52]. Pandita and Fulekar in 2017 and 2019 reported the synthesis of CCPs from eggshell waste [53]. The investigators, have reported the synthesis of micron and nano sized $\mathrm{CaCO}_{3}$ and further transformed them into the $\mathrm{CaO}$ NPs by calcination at $900{ }^{\circ} \mathrm{C}$ for $4 \mathrm{~h}$. They used these $\mathrm{CaO}$ NPs for increasing the efficiency of biodiesel by as micronutrient for the algae the microalgae. Further, Ahmad et al. (2020) has synthesized nano calcium oxide from the eggshell waste and utilized them for the direct transesterification of Chlorella pyrenoidosa. The eggshell was washed properly, crushed by mortar pestle, dried at $105^{\circ} \mathrm{C}$, and calcined at $870{ }^{\circ} \mathrm{C}$ for three hours. The final powder was analyzed by the sophisticated instruments, for their morphological properties. The size of CCPs was varying from 25 to $100 \mathrm{~nm}$. Further they have used these nano $\mathrm{CaO}$ successfully up to six cycles for the transesterification [54]. Figure 3 demonstrates the flowchart of synthesis of $\mathrm{CaCO}_{3}$ from egg shells.

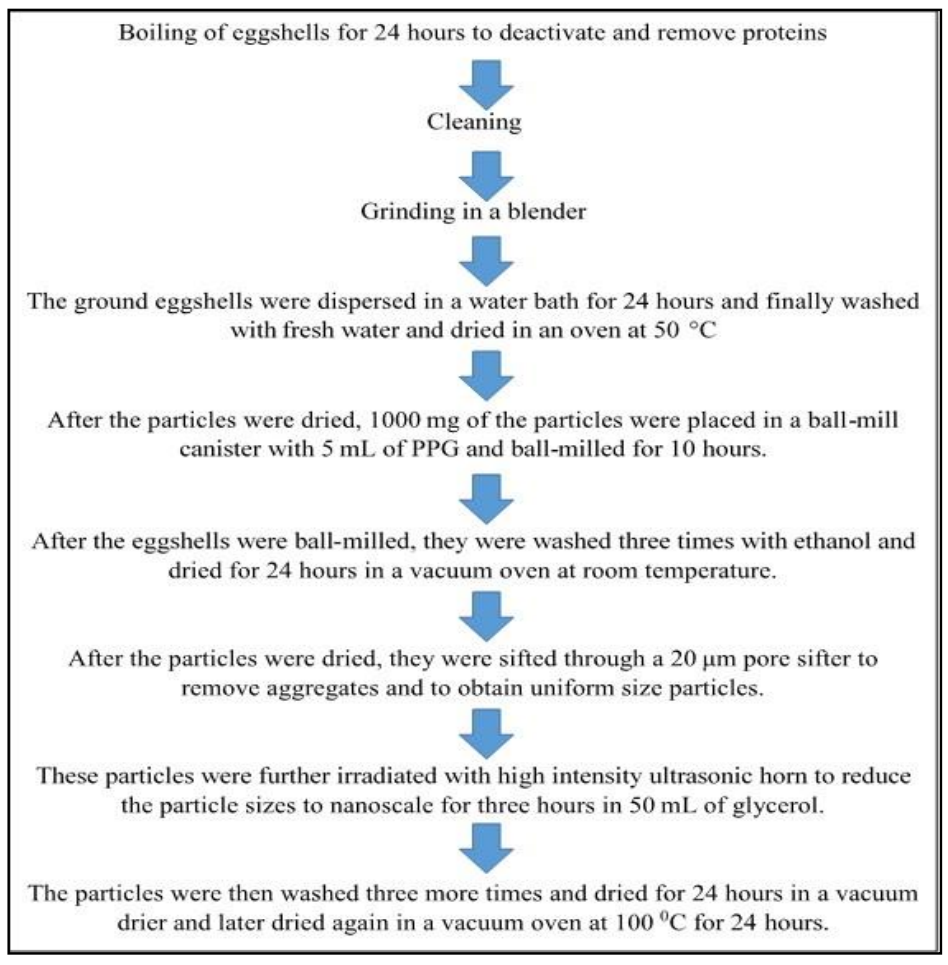

Figure 3. Steps involved in the synthesis of calcium carbonate nanoparticles from eggshell waste. 


\section{Biogenic Waste of Marine Organisms}

\subsection{Shells of Shellfish}

Shellfish are sea animals that belong to the class invertebrates, having mainly two types of animals: crustaceans and mollusks. They mainly include lobsters, shrimps, crayfish, $\mathrm{crab}$, and krill. They have a very hard covering on their external surface which consists of chitin. The shells of such marine organisms have a high content of $\mathrm{CaCO}_{3}$ which is meant for protection from the external environment and predator. After the death of such marine organisms, there is biomineralization of $\mathrm{CaCO}_{3}$ and ultimately calcium ion is added into the seawater [55]. Every year a million tonnes of sea foods are generated in the whole world and major contributors are countries with larger coastal area in the form of their boundary which favors the aquaculture. As far as India is concerned, till 2018, it occupies second rank in aquaculture and third rank in fisheries contributing $1.07 \%$ to the nations GDP. Major, waste of sea foods are heads, trimming residue, tails, shells, and scales. Out of these shell fish soft flesh part is consumed as food while the hard calcareous covering is considered as waste which is mainly dumped of as landfills. Numerous investigators have also reported the synthesis of CCPs from the shells of shellfish. Jaannah et al., 2018, reported the synthesis, characterization, and application of shellfish-derived CCPs for the antibacterial assay [17]. Initially, they synthesized the CCPs and formed a nanocomposite with $\mathrm{MgO}$ which was further assessed for their antimicrobial activity against Escherichia coli and Staphylococcus aureus bacteria. They have also reported the synthesis of $\mathrm{CaCO}_{3} / \mathrm{MgO}$ nanocomposite material by the optimum clear zone and able to utilize shell waste as an antibacterial ingredient of natural materials [17]. The schematic step involved in the synthesis of CCNPs from shellfish is given below in Figure 4.

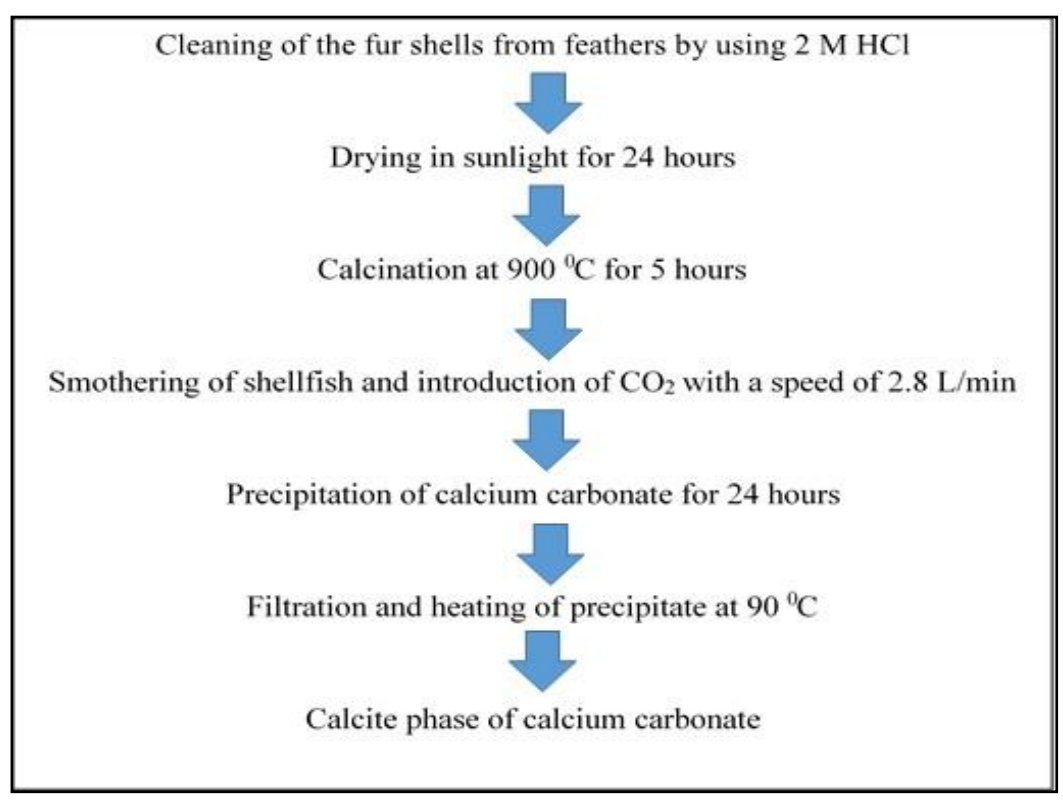

Figure 4. Schematic diagram of extraction of calcite phase from the shellfish.

\subsection{Cockle Shells}

As per the World Fisheries and Aquaculture, USA, 2020, report, about 17,510.9 thousand tonnes of mollusks produced in the 2018, out of which cockle were 433.4 thousand million tonnes, i.e., $2.5 \%$ share of mollusks. Which need to draw the attention towards the cockle shell management otherwise it will lead to the loss of economy in the form of disposal of these cockle shells. So, the recycling of such cockle shells, will not only provide an alternate source of calcium carbonate and their derivatives, but it will also minimize the solid waste. Numerous investigators have reported the recycling of cockle shells for value added materials like calcium oxides and calcium carbonates out of which most recent ones are cited below. 
Majusha Hariharan et al. (2014) synthesized and characterized the nano calcite through the precipitation method from the cockle shells using chitosan as precursor materials. The schematic steps involved in the synthesis of CCNPs from cockle shell are given below in Figure 5. The nano calcite was characterized by SEM, XRD, UV-Vis, and FTIR for confirmation of the particles which was later on compared with the commercial nano calcite. It was found that cockle shells are a potential source of nano calcite, which was byproducts of the seafood industry so the method was cheaper and environment-friendly [50].

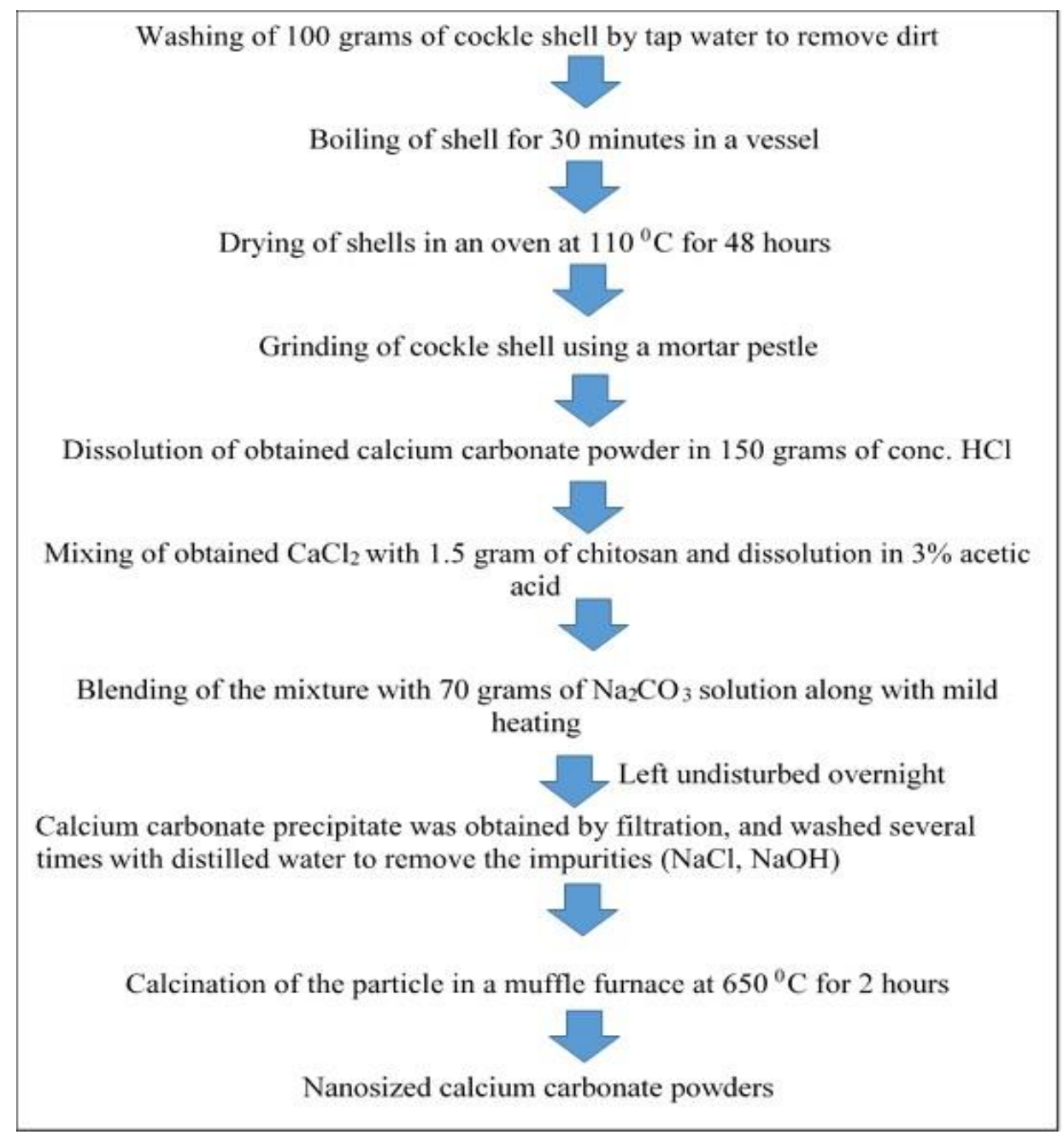

Figure 5. Steps involved in the synthesis of calcium carbonate nanoparticles from cockle shells.

Islam et al. (2012) reported an easy, cost-effective, and novel method for the synthesis of CCPs (aragonite) from the cockle shells whose schematic synthesis is given below in Figure 6. Aragonite is one of the least abundant biogenic polymorphs of $\mathrm{CaCO}_{3}$ which is commonly used as a biomaterial for the repair of the fractured bone, development of advanced drug delivery systems, and tissue scaffolds. The size of obtained aragonite NPs size was $20 \pm 5 \mathrm{~nm}$ with high purity which was confirmed by the variable pressure SEM, transmission electron microscopy (TEM), FTIR, thermogravimetric analyzer (TGA), XRD, and energy-dispersive $\mathrm{X}$-ray spectroscopy [23].

\subsection{From Oyster and Mussel Shells}

Oysters and mussels are also one of the major sea foods consumed in most of the countries around the globe. Out of 17,510.9 thousand tonnes of mollusks produced in 2018, the mussels share was 1205.1 thousand tonnes, i.e., $6.9 \%$ which after processing generates tonnes of shells every day. So, the waste generated from such seafoods maybe requires 
attention towards recycling, otherwise their disposal will lead to the loss of economy [50]. Numerous investigators reported the synthesis of calcium carbonate and oxide from the oyster and mussel shells by various chemical methods out of which most recent ones are cited below.

Washing, boiling and cooling of micron-sized cockle shell powders (Anadara granosa) with tap water

Drying of cockle shell powders in an oven for 7 days

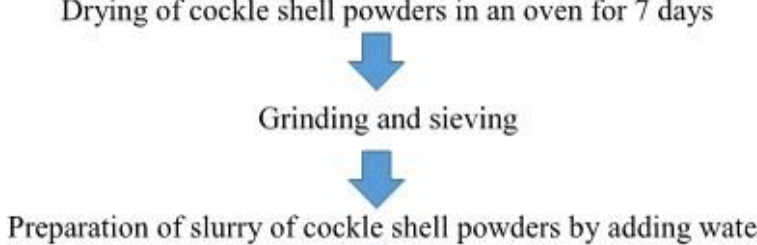

Preparation of slurry of cockle shell powders by adding water

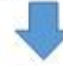

Addition of DMB to the slurry along with vigorous stirring at $1000 \mathrm{rpm}$ at RT for 90 minutes

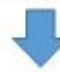

Precipitate was obtained by filtration through double ring filter paper of $18.0 \mathrm{~cm}$ size

Drying of powder at $100{ }^{\circ} \mathrm{C}$ in an oven

$\mathrm{CaCO}_{3} \mathrm{Nps}$ (sized, agglomerated, clumped, and homogenized)

Figure 6. The schematic diagram for the synthesis of calcium carbonate nanoparticles from cockle shells.

Hamester et al. (2011) obtained calcium carbonate from mussel and oyster shells were further used as filler in polypropylene and compared their properties with polypropylene and commercial calcium carbonate composites [56]. For the synthesis of calcium carbonate, the mussel and oyster shells were heated in an oven at $200{ }^{\circ} \mathrm{C}$ for $1 \mathrm{~h}$ to make the shells more brittle and submitted to milling in a high-speed planetary mill with porcelain jar and alumina balls for $15 \mathrm{~min}$ with water. The obtained powders are again heated to $500{ }^{\circ} \mathrm{C}$ and maintained for $2 \mathrm{~h}$. Further, to undo the clusters a new milling was performed without addition of water for $1 \mathrm{~min}$. The resulted powders were characterized by a laser diffraction analyzer and X-ray fluorescence for chemical composition [57].

\section{Recovery from Industrial Waste}

Every year a million tons of industrial waste in the form of gypsum, calcium sulfide, sewage sludge, high calcium fly ash, wollastonite, etc., are produced around the whole world. Most of these are the byproducts of the industries which are generally dumped in the near vicinity of the industries or as landfill [58-60]. The dumping of these waste materials may invite mosquitos and other insects and may lead to various diseases. Moreover, most of these materials are processed materials that have a higher amount of toxic metals that may leach into the land or water bodies and may contaminate them. The aquatic animals may accumulate these toxic metals, i.e., bioaccumulation and lead to bio magnification. So, there is an urgent need to utilize these waste materials for the recovery of value-added materials like calcium. The recovery of calcium-based products from such waste will reduce pollution and provide an alternate source for the $\mathrm{CaCO}_{3}$ particles via a cost-effective and eco-friendly method [61]. Some of the materials that have been used earlier for the synthesis of CCNPs are described below in detail. 


\subsection{Recovery of Calcium Oxide/Carbonate from Sludge}

Sludge is one of the major wastes from houses and industries. Though it has numerous mixtures in it has a high amount of calcium. In a highly populous country like India, about 61,754 million liters per day sewage is generated, and 38,791 MLD is untreated sludge. Every year India produces 277 MTs of solid municipal waste according to estimate of 2016. Whereas this figure is projected to reach to 378.8 MTs in 2030 and 543.3 MTs by 2050. This figure is really need to focus the government and other bodies for recycling and recovery of value added materials from such waste [62,63]. The sludges are reported to have higher percentage of calcium makes it a suitable material for the extraction of CCNPs. Moreover, the raw material is again a waste that needs special treatment for disposal. So, the recovery of $\mathrm{CaCO}_{3}$ from sludge not only reduces solid waste or pollution but also helps in producing valuable minerals from it [64]. The synthesis of $\mathrm{CaCO}_{3}$ from sludge is a low-cost technique, eco-friendly. Till yet an only a countable number of works is done in this filed.

The recovery of CCNPs from the waste sludge by the flotation technique [65]. They investigated the effective dosage of floating agents such as sodium oleate and sunlight dish liquid) and the percent solids of the slurry. They have used floating sieved and un-sieved materials and $\mathrm{CaCO}_{3}$ was estimated for both conditions as well as from tailings. Initial $\mathrm{CaCO}_{3}$ analysis for the bulk material indicated that sieved and un-sieved materials had $63.4 \%$ and $32.9 \% \mathrm{CaCO}_{3}$ content by weight, respectively. Therefore, it was concluded that for un-sieved material sunlight dishwashing liquid was a better collector compared to the latter. The results proved that there is a great potential for recovering commercial-grade limestone from wastewater sludge.

\subsection{Recovery of Calcium Carbonate/Oxide from Dolomite}

Dolomites $\left[\mathrm{CaMg}\left(\mathrm{CO}_{3}\right)_{2}\right]$ are anhydrous carbonate minerals of calcium and magnesium carbonate [66]. It is widely used in the steel and industries. Such iron or steel based industries produces $40-70 \%$ byproducts including dolomite as waste. In general, dolomite is used for the preparation of precipitated $\mathrm{CaCO} 3$ by separating $\mathrm{Ca}$ and $\mathrm{Mg}$ fractions. The major problem in their separation from dolomite is that both the elements have a lower solubility in the water [67]. Some investigators have successfully used sucrose for the extraction of $\mathrm{Ca}$ and $\mathrm{Mg}$ from dolomite. When the calcinated dolomite is dissolved in a sucrose solution, then there is the conversion of $\mathrm{CaO}$ into calcium sucrate leaving unreacted $\mathrm{Mg}$ in the mixture as a precipitate [68]. When calcined dolomite $(\mathrm{CaO} . \mathrm{MgO})$ is dissolved in a sucrose solution, $\mathrm{CaO}$ will be converted into soluble calcium sucrate, while $\mathrm{MgO}$ remains unreacted and presents in the precipitated form [69]. Figure 7 illustrations the stepwise synthesis of CCPs from dolomite.

\subsection{Synthesis of Calcium Oxide/Carbonate Particles from Gypsum Waste}

Gypsum waste is a waste product of the reverse osmosis (RO) desalination process [70]. Gypsum is widely used for dental applications [71] which on disposal into the environment may challenge as a hazardous material. When such gypsum are landfilled into the environment, there is a reaction with biodegradable waste which may produce poisonous and odorous hydrogen sulfide gas [72,73]. Gypsum alone is widely used in the dentistry in hospitals and medical colleges. Every year one medical college produces $100-500 \mathrm{~kg}$ of gypsum waste which could vary based on the patient footfall per year. As per the literature, there are about 345 dental colleges in India, so approximately these colleges generates about 173 tonnes of gypsum waste. In addition, gypsum waste is also generated from various construction site, industries, and mineral processing industries. Gypsum waste can be thermally reduced into $\mathrm{CaS}$, which is then subjected to a direct aqueous carbonation step for the generation of $\mathrm{H}_{2} \mathrm{~S}$ and $\mathrm{CaCO}_{3}$. CaS can be successfully converted into $\mathrm{CaCO}_{3}$; however, the reaction may yield low-grade carbonate products $\left(99 \%\right.$ as $\left.\mathrm{CaCO}_{3}\right)$ or precipitated $\mathrm{CaCO}_{3}$ can be developed and optimized [70]. 


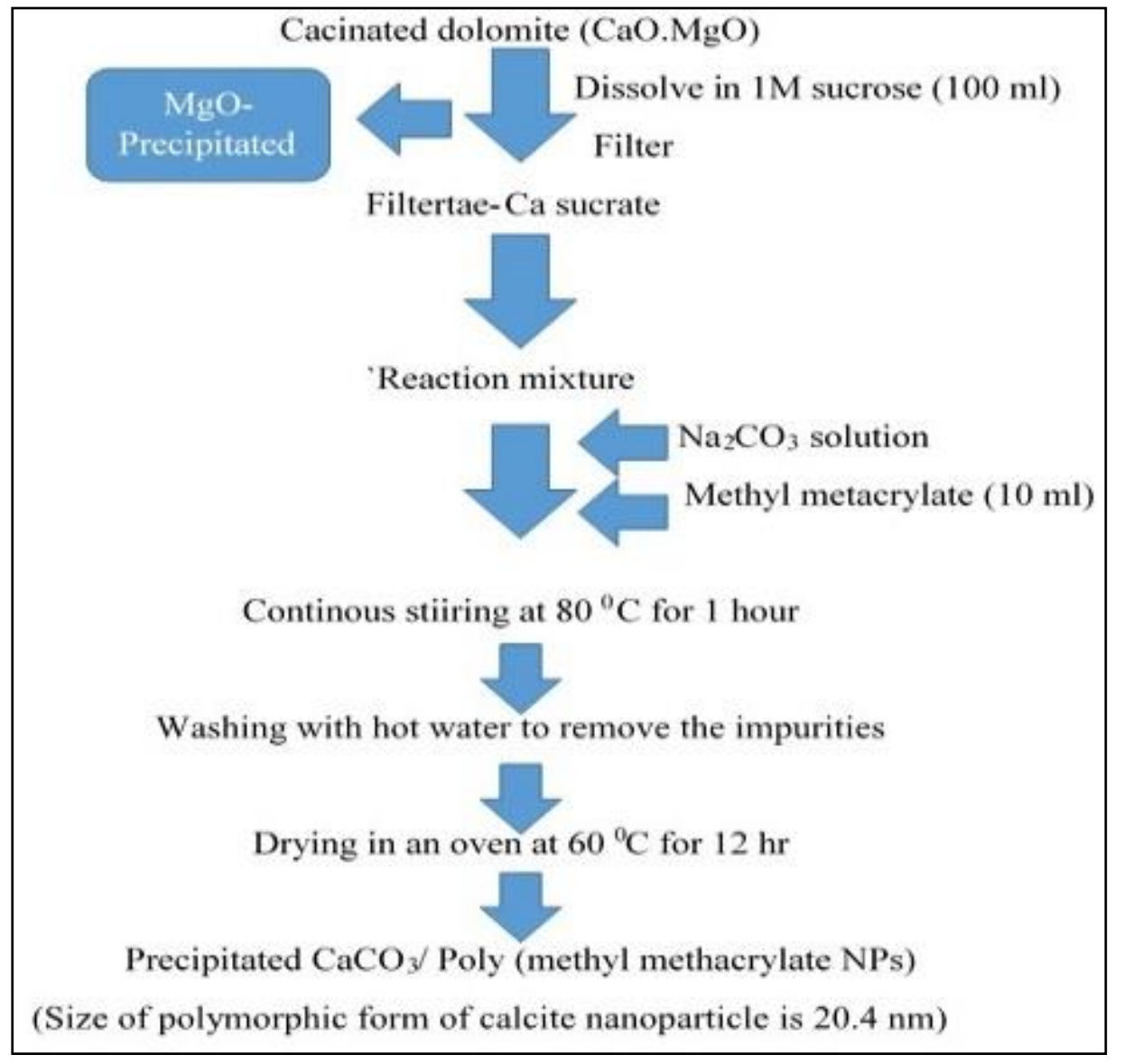

Figure 7. Steps involved in the synthesis of calcium carbonate nanoparticles from dolomite.

Beer et al. (2014) reported the synthesis of CCPs from the gypsum waste, where elemental sulfur was the by-product. Here the first step was the thermal reduction of gypsum waste into calcium sulfide $(\mathrm{CaS})$ followed by its direct aqueous carbonation yielded low-grade carbonate products or precipitated $\mathrm{CaCO}_{3}$. The process used an acid gas $\left(\mathrm{H}_{2} \mathrm{~S}\right)$ to improve the aqueous dissolution of $\mathrm{CaS}$, which is otherwise poorly soluble. The carbonate product was primarily calcite $(99.5 \%)$ with traces of quartz $(0.5 \%)$. Calcite was the only $\mathrm{CaCO}_{3}$ polymorph obtained; no vaterite or aragonite was perceived. The schematic steps involved in the synthesis of CCNPs from gypsum waste are shown below in Figure 8 . The product was made up of micron-size particles, which were further characterized by XRD, TGA, SEM, Bruner-Emmett-Teller (BET), and true density. The batch recovery of $\mathrm{CaCO}_{3}$ from waste gypsum slurry using sodium carbonate under ambient conditions that were further utilized for pre-treatment of acid mine drainage from coal mines [70]. US patent no 2013/0288887 A1 reported a simple, cost-effective, and novel method for the recovery of nano $\mathrm{CaCO}_{3}$ from the gypsum waste slurry [74]. There is a lower decomposition temperature of $\mathrm{CaCO}_{3}$. The synthesized nano $\mathrm{CaCO}_{3}$ was used as a nano adsorbent for the adsorption of carbon dioxide, and as a complex catalyst for reactive sorption enhanced the reforming process for hydrogen production from methane. The CaO-based carbon dioxide adsorbent shows good cycle stability and fast sorption rate, and complex catalyst used for reactive sorption enhanced methane steam reforming can obtain the hydrogen with a purity of more than $90 \%$.

The CCPs can be synthesized by a simple thermal decomposition method [75], where the dolomite is calcined at $800{ }^{\circ} \mathrm{C}$, and it is decomposed into $\mathrm{CaCO}_{3}$ and $\mathrm{CaO}$ in the presence of air. The major disadvantage with this method is that there are adsorption and precipitation of $\mathrm{AsCO}_{3}$ and $\mathrm{AsO}$ [76]. Chilakala et al. (2016) reported an innovative convenient, and cost-effective carbonation method for the synthesis of pure aragonite 
needle phase of CCPs from dolomite [77]. The characterization of PCC was done by $X R D$ and SEM for the morphological and mineralogical and aspect ratio (ratio of length to the diameter of the particles). The synthesis of PCC was carried out in two steps, at first, after calcinated, dolomite fine powder was dissolved in water for hydration, the hydrated solution was then mixed with an aqueous solution of magnesium chloride at $80^{\circ} \mathrm{C}$, and then $\mathrm{CO}_{2}$ was bubbled into the suspension for three hours to produce aragonite PCC. Finally, aragonite type precipitated $\mathrm{CaCO}_{3}$ can be synthesized from natural dolomite via a simple carbonation process, yielding a product with an average particle size of 30-40 $\mu \mathrm{m}$ [78].

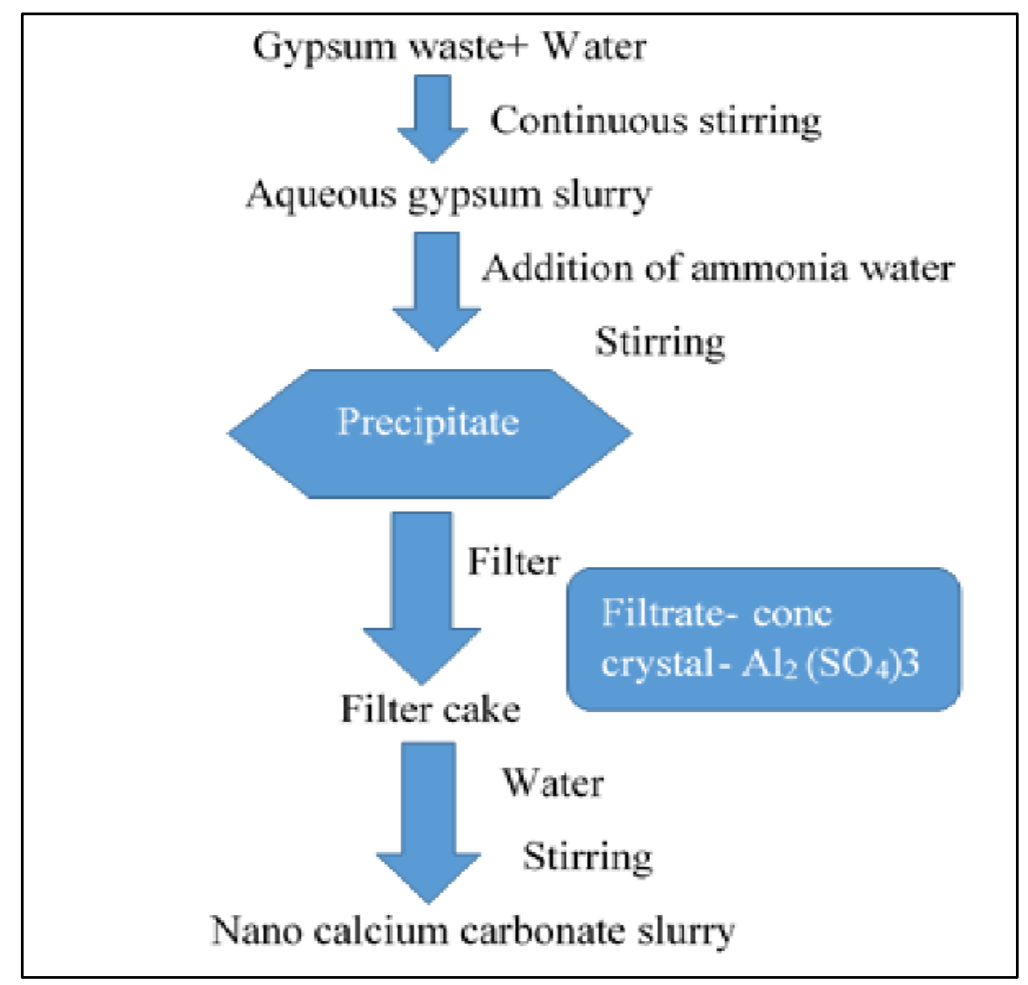

Figure 8. Steps involved in the synthesis of calcium carbonate nanoparticles from gypsum waste.

\subsection{Recovery of Calcium Oxide/Carbonate Particles from Finger Citron Residue}

About two-thirds of the world's citrus fruits are produced by Brazil, China, India, Mexico, Spain, and the USA. In 2016, about 124 Million gallons of citrus fruits were produced out of which $50-60 \%$ used as fresh fruits while the remaining $40-50 \%$ was subjected to industrial processing for extraction of juices, etc. Based on the applied technology and type of cultivars, the citrus peel waste of such industries varies from 50 to $70 \% w / w$ of processed fruits $[79,80]$. This leads to the generation of $10 \mathrm{Mg}$ of citrus peel waste, which has moisture whereby it attracts flies, insects, and mosquitoes and leads to the pollution. So, it is important to process the citrus peel waste for the recovery of value added materials. One such citrus fruit is finger citrons (FG) whose shape is unusual and the fruit is segmented into finger-like sections [81]. Finger citron, which is a subtropical plant, is grown in China's Sichuan, Fujian, Guangdong, and Zhejiang provinces [82]. In the time of finger citron beverage processing, a huge amount of Finger citron residues (FCRs) are produced which is disposed of as garbage Such disposals sometimes may give rise to other environmental problems [83]. It has a porous texture and contains numerous organic compounds which makes them a preferable precursor material for the synthesis of porous materials that can also be potentially applied for environmental protection. They are almost similar to lemon and used as a substitute for lemon in China. FCR is the residual of the fruit after extraction of juices from it. The FCR is reported to have numerous valuable minerals and elements 
but it has a high amount of Ca which makes them a suitable material for the extraction of CCPs. The synthesis mechanism of CC NPs from FCR is given below in Figure 9.

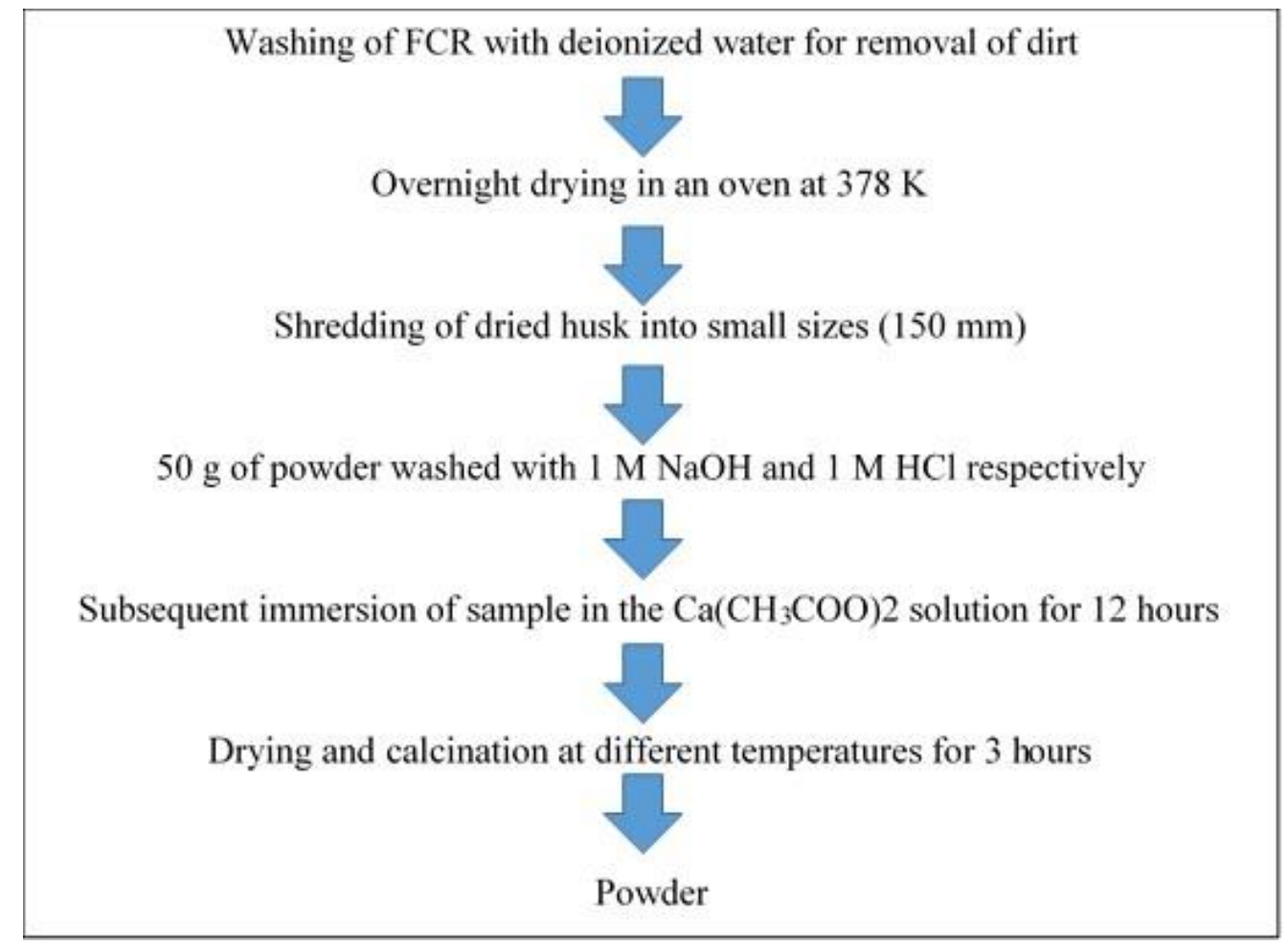

Figure 9. Steps involved in the synthesis of calcium carbonate nanoparticles from finger citron residue.

\subsection{Recovery of Calcium Oxide/Carbonate from Waste Calcium Sulfide}

Calcium sulfide (CaS) is one of the major waste of several industries which are based on coal [84]. This is a waste material that is produced in large amounts for example, gasification of 1000 tons/day of $3 \%$ sulfur coal produces 67 tons/day of CaS) during the desulfurization of hot coal gas by a limestone-based adsorbent. The main problem with such waste is that it is rich in sulfur so cannot be landfilled as there could be potential $\mathrm{H}_{2} \mathrm{~S}$ gas evolution and leaching of sulfur in the soil. Brooks and Lynn (1997) reported the synthesis of $\mathrm{CaCO}_{3}$ and $\mathrm{H}_{2} \mathrm{~S}$ from the waste $\mathrm{CaS}$ where, the calcium sulfide is dissolved by reacting with $\mathrm{H}_{2} \mathrm{~S}$ forming a complexed either with aqueous methyl diethanolamine (MDEA) or other alkanolamines [85]. Further, in the very next stage, $\mathrm{Ca}(\mathrm{HS})_{2}$, which is extremely soluble, reacts with $\mathrm{CO}_{2}$ complexed with MDEA (aqueous). These precipitates the pure and uniformly sized crystalline $\mathrm{CaCO}_{3}$ and to forms MDEA-complexed hydrogen sulfide.

\subsection{Synthesis of Calcium Carbonate from Yellow Phosphorus Slag}

Chen et al. (2020) used yellow phosphorus slag as a raw material to obtain high-purity calcium carbonate whiskers at low temperature and pressure. During the experiments, the effect of reaction conditions, i.e., temperature, time, concentration of $\mathrm{Ca}^{2+}$, ammonia dosage, and $\mathrm{CO}_{2}$ flow rate was systematically discussed by researchers. The above mentioned parameters have an important effect on the crystal shape and microscopic morphology of the product. It was found that the content of calcium carbonate (aragonite) in the product was about $93.67 \%$ under optimal conditions. The whiteness of the product was $97.6 \%$. The single particle diameter was found to be about 1.5-3 $\mu \mathrm{m}$, and the length of a single particle was about $8-40 \mu \mathrm{m} . \mathrm{SiO}_{2}$ was produced as by-products during the whole preparation process could also be reused [86]. Researches indicated that the production strategy had a good application prospect. 


\section{Characterization of Calcium Carbonate and Oxide Particles}

The characterization of calcium carbonate NPs (CCNPs) can be done by all the sophisticated instruments but especially by FTIR, XRD, scanning electron microscopy-electron diffraction spectroscopy (SEM-EDS), TEM, and Raman spectroscopy. The characterization of CCNPs plays an important role in the confirmation of synthesis and identification of polymorphs. Fourier transform infrared spectroscopy plays an important role in the identification of functional groups in the synthesized CCNPs. A typical FTIR spectrum of a CCNPs is shown in Figure 10. The FTIR analysis of $\mathrm{CaCO}_{3}$ reveals that there is a strong peak for carbonate ions due to vibration peaks $v 1$, symmetric stretching; $v 2$, outof-plane bending; $v 3$, doubly degenerate planar asymmetric stretching; and $v 4$, doubly degenerate planar bending. The spectrum shows vibrational bands at 1456.3, 876.7, 712.7, and $409.8 \mathrm{~cm}^{-1}$ indicates plane bending vibration of carbonate [87]. The FTIR analysis confirmed that the $\mathrm{CaCO}_{3}$ nanopowder had the characteristic peak of the carbonate group. A sharp peak at $876.7 \mathrm{~cm}^{-1}$ confirmed that the $\mathrm{CaCO}_{3}$ nanopowder obtained from the cockleshell was calcite.

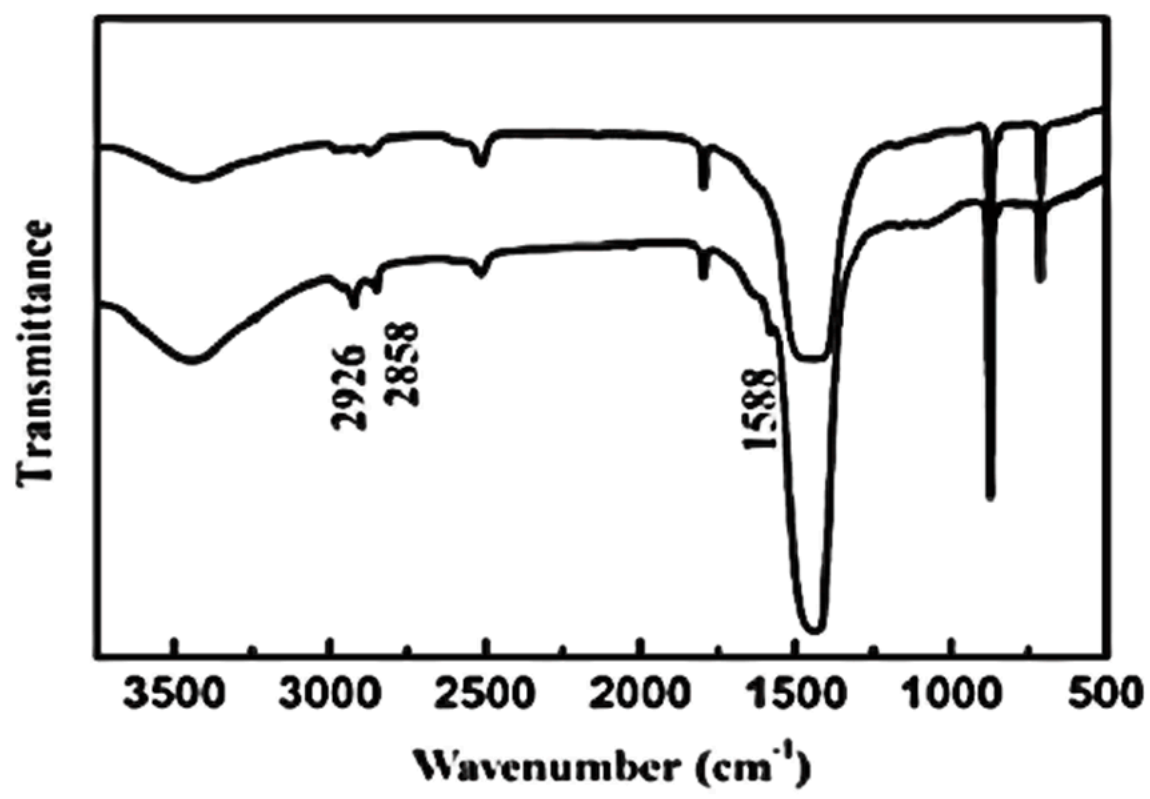

Figure 10. Fourier transform infrared spectra of calcium carbonate nanoparticles adapted from Chen et al., 2010.

Similarly, Raman spectroscopy also helps in the identification of molecules and functional group identification. The most important technique is the SEM which helps in the differentiation among the three polymorphs of CCNPs otherwise all these three polymorphs will look alike. The TEM also helps in the size determination of the particles. Based on the external morphology these polymorphs can be easily recognized as nano calcite. They are rhombohedral in shape, aragonite is needle-shaped and the vaterite is either spherical or flower shape. The typical field emission scanning electron microscope images of nano calcite, aragonite, and vaterite are shown in Figure 11a-d. The rhombohedral shaped particles confirm the calcite phases whose surface is smooth with sharp edges and corners [88].

Figure $11 \mathrm{~b}$ is showing the aragonite phase, which is rod-shaped. The vaterite phase in Figure 11c,d is showing flower and spherical shape. The EDS attached with SEM helps in the confirmation of the formation of $\mathrm{CaCO}_{3}$ along with its purity. The EDS also reveals the purity of the CCNPs by giving a molecular percentage of elements mainly $\mathrm{C}, \mathrm{O}$, and $\mathrm{Ca}$ in the elemental spectra. While the TEM image in Figure 12A reveals a rhombohedral shaped micron particle whose morphology is similar to the SEM images in Figure 12A [88]. 

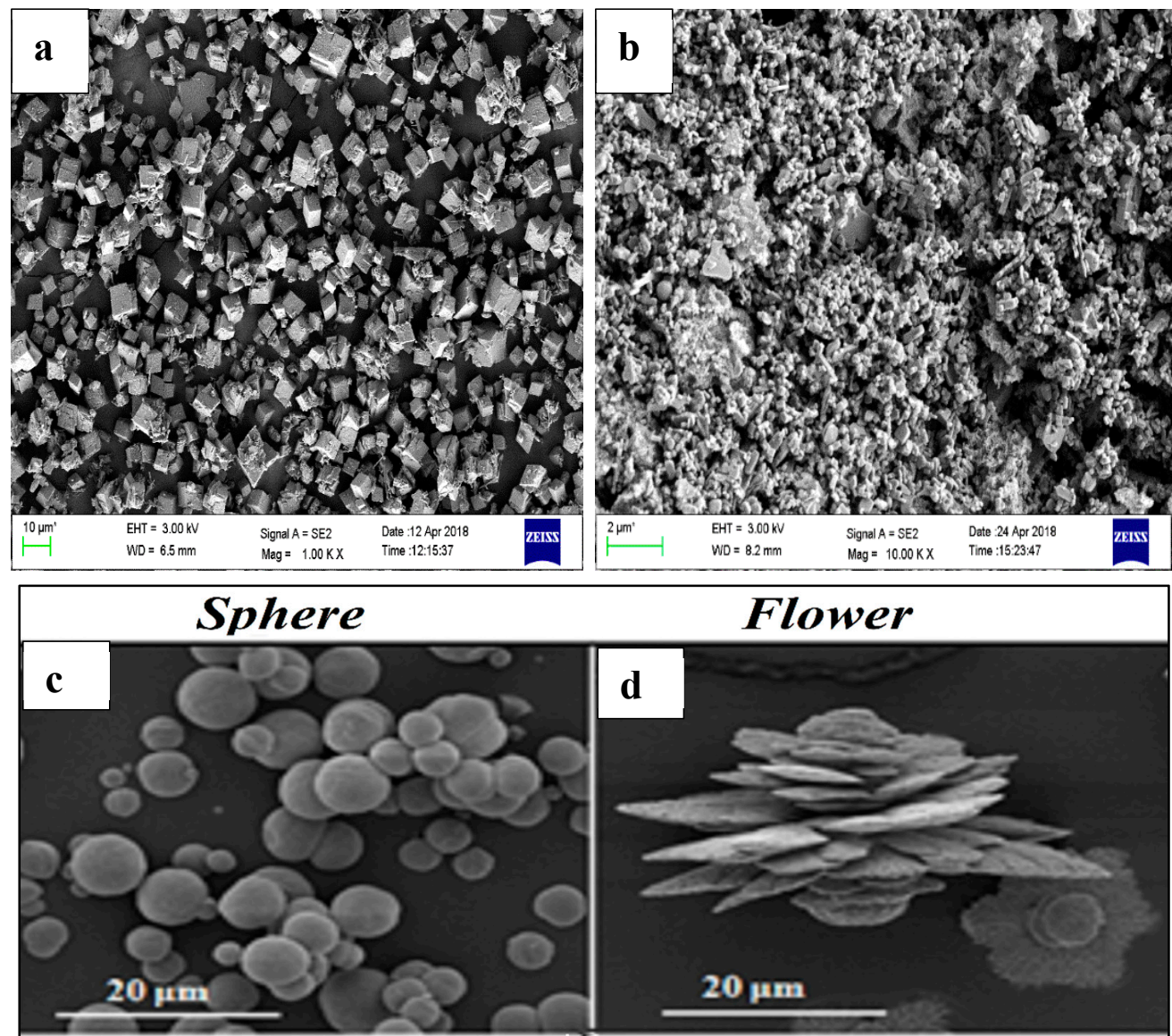

\begin{tabular}{|l|c|}
\hline $0.2-5 \mu \mathrm{m}$ & $20-100 \mu \mathrm{m}$ \\
\hline Vaterite $\left(\mu-\mathrm{CaCO}_{3}\right)$ & Vaterite $\left(\mu-\mathrm{CaCO}_{3}\right)$ \\
\hline Hexagonal & Hexagonal \\
\hline \hline
\end{tabular}

Figure 11. FESEM of (a) nano calcite; (b) aragonite; (c) spherical vaterite; (d) floral vaterite [89].

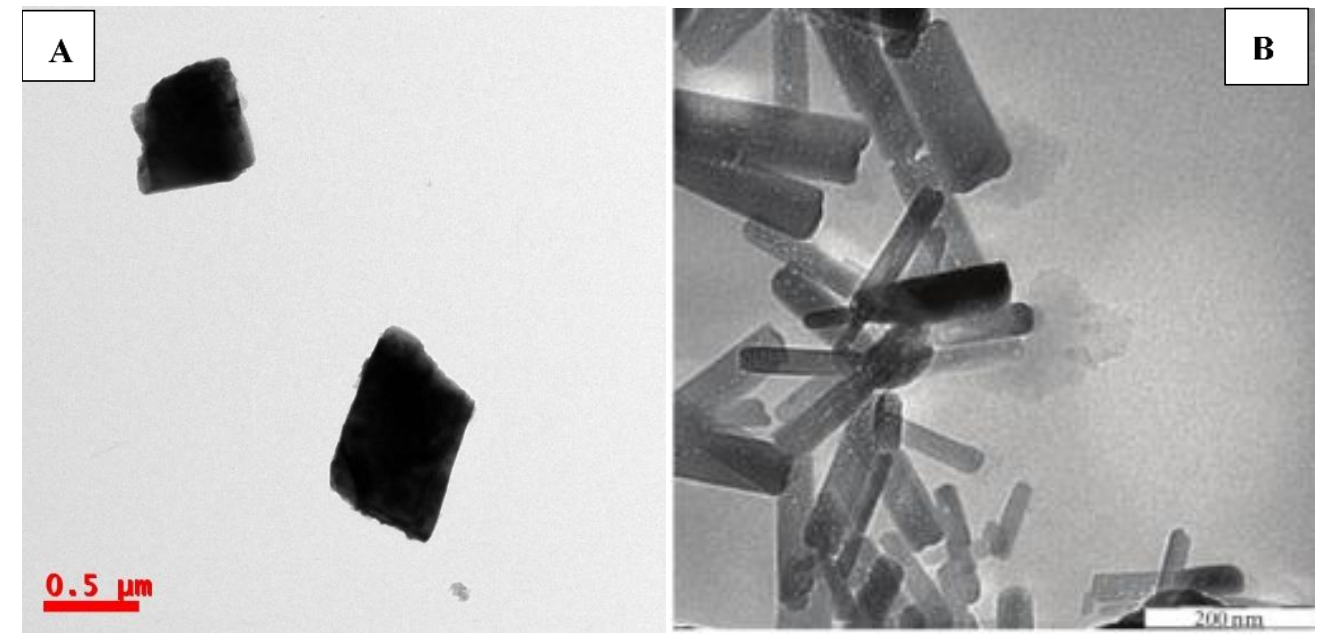

Figure 12. Transmission electron microscopic images of (A) calcium carbonate of microparticles and (B) aragonite nanorods adapted from (Islam et al., 2012). 
While Figure 12B is showing nanorods whose diameter in width is below $50 \mathrm{~nm}$ and the length is above $200 \mathrm{~nm}$. The rod-shaped particles indicate the aragonite phase of $\mathrm{Ca}$ NPs [88].

X-ray diffraction (XRD) analysis helps in the confirmation of mineralogy and phase determination of the CCNPs. A typical XRD pattern is shown in Figure 13, which exhibits characteristics peaks of aragonite at $2 \theta$ values of $26.34^{\circ}, 33.24^{\circ}, 45.98^{\circ}, 33.24^{\circ}, 45.98^{\circ}$, and $26.3^{\circ}$, which correlate with (hkl) indices of (111), (012), (221), and (021), (0.12), and (221), respectively [23].

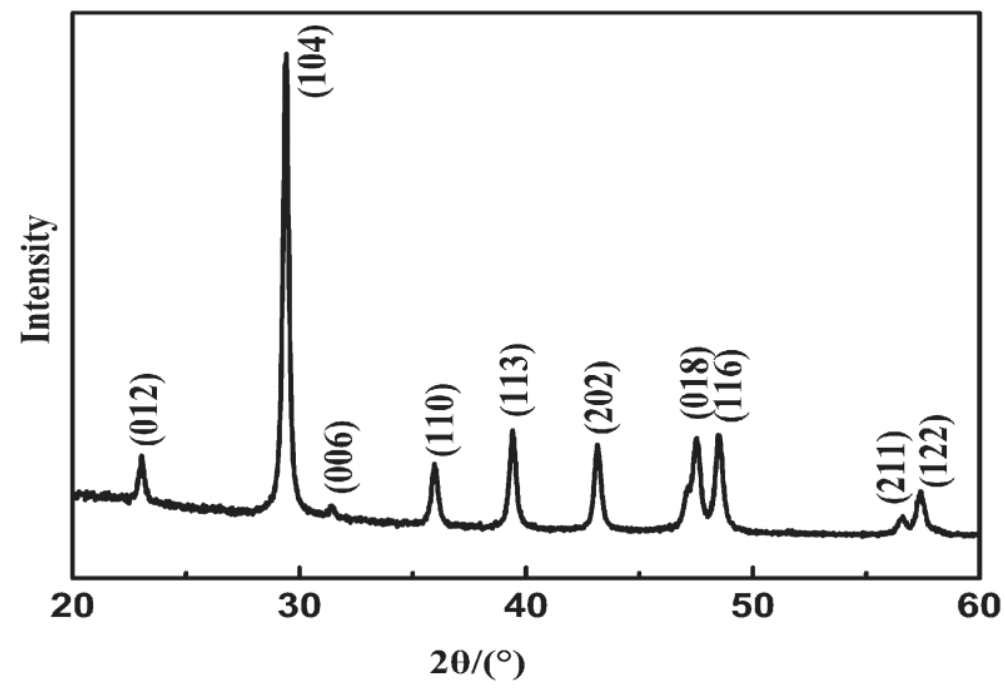

Figure 13. X-ray powder diffraction (XRD) spectrum of calcium carbonate nanoparticles adapted from Chen et al., 2010 (Chen et al., 2010).

\section{Applications of Calcium Carbonate Nanoparticles}

$\mathrm{CaCO}_{3}$ is one of the materials which are used very frequently in the fields of ceramics [23], medicine, drug delivery, paints, fertilizers, food, cosmetics and drugs, papers, fillers, inks [9], catalysts, rubbers, plastics, and paints. In most of these industries, it is used as a viscosity modifier. It is also used as a nano adsorbent for the remediation of pollutants from the wastewater.

\subsection{Applications of Calcium Carbonate Particles for Environmental Cleanup}

The application of CCPs in the field of environmental cleanup is very significant due to the low cost of the nanoparticle, easy availability, and biocompatible nature [23]. It can be used for the removal of both organic as well as organic pollutants from the wastewater. Moreover, the insolubility of $\mathrm{CaCO}_{3}$ in water makes them more suitable for application in aqueous solutions [90]. Among inorganic pollutants, it can be applied for the removal of heavy metals [91] from the wastewater [92], while the organic pollutants that can be removed by CCPs are phenols, pesticides, and dyes [93]. In addition, it can also be used as a nano biosensor for the detection and removal of pollutants (microbial, chemical). All these examples are given below where CCPs have been used for the remediation of inorganic and organic pollutants.

\subsection{Heavy Metals Removal}

Heavy metals contamination is one of the serious nuisances in the area of water and wastewater management. The elimination of heavy metals from the aqueous solutions is carried out by numerous methods that we have already seen above in the introduction section. We know that adsorption is a reliable, economical, and efficient technique [94]. Some of the most common adsorbents are zeolites, activated carbon, alumina, zinc oxide, etc. Here the size of adsorbents falls in the size of microns, so the process is less efficient. 
When adsorption is done employing biological material like microbes then the process is called bioremediation [95]. When biological material and NPs are used together with either by surface modification or in the form of composite, the process is called nano bioremediation. When the adsorption process is carried out by NPs then the process is called nano remediation [96]. In the above section, we have already seen the advantages of CCPs as an adsorbent. So, here we have highlighted the examples where CCPs have been applied for the removal of heavy metals and other pollutants.

Hong et al., 2011, reported the removal of heavy metals $\left(\mathrm{Cu}^{2+}, \mathrm{Cr}^{6+}, \mathrm{Cd}^{2+}\right.$, and $\left.\mathrm{Pb}^{2+}\right)$ by using calcium carbonate particles extracted from the starfish by using enzymes like alpha-amylase, beta-amylase, and protease. It was found that the obtained adsorbent were comparatively effective in the heavy metal removal than the calcium carbonate obtained from crabs, oyster, and cockle shells. Moreover, the calcium carbonate was highly porous in nature, which again made them suitable and effective candidate for the remediation of heavy metals [91].

The remediation of heavy metals from the aqueous solution by using CCPs synthesized through chemical method metals [97]. In this experiment, $\mathrm{CaCO}_{3}$ was used to remove the $\mathrm{Fe}$ and $\mathrm{Pb}$ ions from the aqueous solutions and studied the adsorption mechanism including the kinetic and isotherm models at room temperature. From the above study following findings were obtained: (i) adsorption kinetics follows a pseudo-second-order equation; (ii) Langmuir isotherm revealed that the maximum monolayer adsorption capacity of $\mathrm{CaCO}_{3}$ for $\mathrm{Pb}$ (II) was $1210 \pm 30 \mathrm{mg} / \mathrm{g}$ and for Fe (II) ions, it was $845 \pm 8 \mathrm{mg} / \mathrm{g}$; (iii) optimal dose of $\mathrm{CaCO}_{3}$ was $200 \mathrm{mg} / \mathrm{L}$ at $25^{\circ} \mathrm{C}$, and (iv) and the removal efficiency of $\mathrm{Fe}$ and $\mathrm{Pb}$ ions is enhanced by a precipitation transformation mechanism instead of adsorption.

Jacob et al. (2018) reported the use of $\mathrm{CaCO}_{3}$ coated bacterial magnetosomes (biogenic magnetite obtained from the internal structures of magnetotactic bacteria) for remediation of $\mathrm{Cr}$ (III) and $\mathrm{Ni}$ (II) ions from tannery effluent. The following findings were observed from the experiment.

(i) Equilibrium was attained within an hour for $\mathrm{Cr}$ (III) ions at $\mathrm{pH}-6.0$ and $\mathrm{Ni}$ (II) ions at a $\mathrm{pH}-8.0$.

(ii) The adsorption process followed a pseudo-second-order reaction kinetics, along with Langmuir and Freundlich adsorption isotherms.

(iii) Adsorption of metallic ions on calcite microcrystals was spontaneous and endothermic.

(iv) Almost equal removal efficiency (Cr-94\% and Ni-84\%) was observed with both magnetic calcite and calcite crystals but it was higher than magnetosomes and activated carbon.

(v) Removal of both the metal ions was facilitated by applying an external magnetic field.

(vi) It is concluded that the magnetic calcite could act as a potential and alternative adsorbent for the elimination of heavy metals from tannery effluents [98].

Abeykoon et al. (2017) reported the elimination of the excess of fluoride ions from different water sources from Sri Lanka using porous CCNPs. The reported approach is quite simple, cost-effective, and innovative for the elimination of fluoride ions from the wastewater. The synthesized porous CCNPs removes the fluoride by simple adsorption mechanism and about $100 \%$ removal efficiency was achieved within one hour only [99].

\subsection{As a Biosensor}

CCPs can be used in developing a simple and economical biosensor due to their unique properties like high porosity, high surface area, and low mass transport barrier. Earlier investigators have reported the utilization of CCPs to detect phenols and glucose by immobilizing enzymes polyphenol oxidase (PPO) and glucose oxidase, respectively. The $\mathrm{PPO} /$ nano- $\mathrm{CaCO}_{3}$ electrode possesses a wide detection range (i.e., $6 \times 10^{-9}$ to $2 \times 10^{-5} \mathrm{M}$ ), sub-nanomolar detection limit $(0.44 \mathrm{nM}$ at a signal to noise ratio of 3$)$, good stability (70\% remained after 56 days), the shorter response time (i.e., $<12 \mathrm{~s}$ ), large current density, and very high sensitivity (i.e., $474 \mathrm{~mA} / \mathrm{M})$. Similarly, the glucose biosensor also provided the same benefits and was very little influenced by other compounds (like ascorbic acid, glutathione, L-cysteine, and p-acetaminophenol) at their normal levels. The development 
of a highly sensitive amperometric phenol biosensor by using CCNPs of size around $80 \mathrm{~nm}$. The sensor was developed by casting (nano- $\mathrm{CaCO}_{3}$ )-PPO bio composite on the surface of a glassy carbon electrode by glutaraldehyde cross-linking. The special three-dimensional structure, porous morphology, hydrophilicity, and biocompatibility of the nano- $\mathrm{CaCO}_{3}$ matrix provided high enzyme loading, and the enzyme entrapped in this matrix retained its activity to a large extent. In addition, the effects of $\mathrm{pH}$ value applied potential, temperature, and electrode construction were also studied [100]. In one of the experiments, investigators have used the polyelectrolyte capsules (with or without $\mathrm{CaCO}_{3}$ core) as a $\mathrm{pH}$ indicator that works even in the presence of salt in the solution. High removal capacities of heavy metals, i.e., $\mathrm{Cd}^{2+} 515, \mathrm{~Pb}^{2+} 1028, \mathrm{Cr}^{3+} 259, \mathrm{Fe}^{3+} 321$, and $\mathrm{Ni}^{2+} 537 \mathrm{mg} / \mathrm{g}$ were achieved from aqueous solutions using precipitated amorphous calcium carbonate (ACC) NPs. The removal process was via precipitation, so the ACC became non-reusable. Few investigators have developed multi-structured $\mathrm{CaCO}_{3} /$ magnetite composite crystals by microwave radiation method which was used for the photocatalytic splitting of water to liberate oxygen. One special advantage with such photocatalyst is that it can be recycled after extraction from the solution.

\subsection{Phenolic Compounds Removal}

Phenolic compounds are a class of polluting chemicals, which are exploited extensively and discharged into the environment. These phenolic compounds have a high tendency to be absorbed by living beings from their skin and mucous membranes. Therefore, it is of utmost importance to determine the content of phenolic compounds due to their toxicity and persistent nature in the environment. a biosensor is one of the most important tools for the detection of such phenolic compounds, out of which amperometric biosensor based on PPO or tyrosinase is most widely used for the detection of phenols due to its effectiveness and simplicity [101]. PPO is a metalloenzyme that contains a binuclear copper active site and catalysis, in the presence of dioxygen, the hydroxylation of monophenols to catechols (monooxygenase activity), which in turn are oxidized to ortho-quinone (catecholase activity). The phenol biosensor transduction is thus based on the amperometric detection of the enzymatically generated o-quinone.

\subsection{Dye Removal}

Mosleh (2018) synthesized 15-50 nm, cobalt tungstate, and $\mathrm{CaCO}_{3}$ nanocomposite for the removal of organic pollutants (dyes) from the wastewater. The morphological and chemical properties were analyzed by vibrating sample magnetometer, UV-Vis diffuse reflectance spectroscopy, XRD, and SEM where the latter two instruments helped in the confirmation of the average crystallite size of nanocomposites, whose size was in the range 15-50 nm. The high absorption with $3.2 \mathrm{eV}$ bandgap of synthesized nanocomposite was identified with the DRS spectrum. The synthesized nanocomposite exhibits photocatalytic activity which was used for the degradation of methyl violet, methylene blue, phenol red, and eosin Y dyes. The developed nanocomposite degraded the MV dye up to $99 \%$, within $200 \mathrm{~min}$ [102]. Ma et al. reported the synthesis of CCNPs from finger citron residue (FCR) that have already been discussed above in the synthesis section and utilized them for the removal of Congo red (CR) from the wastewater [82]. Here Nickel-doped porous $\mathrm{CaCO}_{3}$ monoliths were developed from the FCR and applied for the removal of anionic dye CR by adsorption method in a batch experiment. The adsorption of CR by such NPs showed a pseudo-second-order kinetic model and Langmuir adsorption isotherm. It was found that due to the differences in positive and negative charge effects between CR and Nickel, a higher amount of CR dye was adsorbed on the Nickel-doped porous $\mathrm{CaCO}_{3}$ monoliths which authenticate that later are a promising adsorbent for the removal of the anionic dyes from wastewater.

The removal of various organic and inorganic pollutants from different water and wastewater indicates that the main process for the removal of pollutants was adsorption. In some cases, CCPs were without surface functionalized while in some cases the CCPs 
surface were modified by various capping agents. These capping agents were used in order to make the CCPs more specific for a specific pollutants. The adsorption is a simple technique which is practiced from a century to remediate the pollutants. In this process inorganic pollutants like heavy metals gets reduced on the surface of the CCPs. Due to this reduction, the toxic heavy metals gets converted into nontoxic form which is beneficial for the flora and fauna. Moreover, adsorption process do not involve any sophisticated instruments, and machinery so it is considered easy, and economical. The only problem faced is the disposal or recycling of the CCPs loaded with the toxic heavy metals.

\section{Conclusions}

The CCPs have enormous potential in the field of electronics, medicine, drug delivery, paints, feed supplements, and environmental cleanup due to their biocompatibility, biodegradability, and low cost. However, the recovery of CCPs makes all these properties more justified, which further lowers the cost of the product and minimizes the pollution on the environment. Undoubtedly, the recovery of CCPs from the waste by products like fly ash, incense sticks ash, egg shell, cockle shell, gypsum, and dolomite provides an alternative for the calcium-based industries. The CCPs exhibit three polymorphisms, viz., calcite, aragonite, and vaterite. These polymorphs vary in the stability of the particle. The CCPs have the potential for the remediation of heavy metals, pesticides, dyes, and other pollutants from the wastewater. Moreover, the biodegradable, biocompatible, and economical nature of CCPs make the process of adsorption much economical.

Author Contributions: Conceptualization, V.K.Y., N.C.; methodology, V.K.Y., K.K.Y. and S.P.; validation, N.C., G.G., M.M.S.C.-P. and A.H.K.; formal analysis, V.K.Y., K.K.Y., N.C. and G.G.; resources, N.A.K., S.I., M.M.S.C.-P. and A.H.K.; writing-original draft preparation, V.K.Y.; writing-review and editing, V.K.Y., S.P., V.T. and N.C.; supervision, V.K.Y., A.H.K., V.T. and S.P.; project administration V.K.Y., K.K.Y., S.I., N.A.K. and V.T. Funding acquisition, A.H.K., S.I., N.A.K. and M.M.S.C.-P.; Software's, V.T., S.P., M.M.S.C.-P., N.C., S.I., N.A.K. and A.H.K. All authors have read and agreed to the published version of the manuscript.

Funding: The authors thankfully acknowledge the Deanship of Scientific Research, King Khalid University, Abha, KSA, for funding the project under the grant number R.G.P.1/201/41.

Institutional Review Board Statement: Not applicable.

Informed Consent Statement: Not applicable.

Data Availability Statement: Not applicable.

Acknowledgments: The authors thankfully acknowledge the Deanship of Scientific Research, King Khalid University, Abha, KSA, for funding the project under the grant number R.G.P.1/201/41.

Conflicts of Interest: The authors declare no conflict of interest.

\section{References}

1. Wagh, R.; Dongre, A. Agricultural Sector: Status, Challenges and it's Role in Indian Economy. J. Commer. Manag. Thought 2016, 7, 9. [CrossRef]

2. Khan, M.; Khan, A.U.; Hasan, M.A.; Yadav, K.K.; Pinto, M.M.C.; Malik, N.; Yadav, V.K.; Khan, A.H.; Islam, S.; Sharma, G.K. Agro-Nanotechnology as an Emerging Field: A Novel Sustainable Approach for Improving Plant Growth by Reducing Biotic Stress. Appl. Sci. 2021, 11, 2282. [CrossRef]

3. Campos, D.A.; Gómez-García, R.; Vilas-Boas, A.A.; Madureira, A.R.; Pintado, M.M. Management of Fruit Industrial By-Products-A Case Study on Circular Economy Approach. Molecules 2020, 25, 320. [CrossRef]

4. Chand Malav, L.; Yadav, K.K.; Gupta, N.; Kumar, S.; Sharma, G.K.; Krishnan, S.; Rezania, S.; Kamyab, H.; Pham, Q.B.; Yadav, S.; et al. A review on municipal solid waste as a renewable source for waste-to-energy project in India: Current practices, challenges, and future opportunities. J. Clean. Prod. 2020, 277. [CrossRef]

5. Quina, M.J.; Pinheiro, C.T. Inorganic Waste Generated in Kraft Pulp Mills: The Transition from Landfill to Industrial Applications. Appl. Sci. 2020, 10, 2317. [CrossRef]

6. Tang, P.; Chen, W.; Xuan, D.; Cheng, H.; Poon, C.S.; Tsang, D.C.W. Immobilization of hazardous municipal solid waste incineration fly ash by novel alternative binders derived from cementitious waste. J. Hazard. Mater. 2020, 393, 122386. [CrossRef] 
7. Sheets, J.L.; Wee, A.G.; Simetich, B.; Beatty, M.W. Effect of Water Dilution on Full-Arch Gypsum Implant Master Casts. Prosthesis 2020, 2, 266-276. [CrossRef]

8. Erdogan, N.; Eken, H.A. Precipitated calcium carbonate production, synthesis and properties. Phys. Probl. Min. Process. 2017, 53, 57-68. [CrossRef]

9. Bicchieri, M.; Valentini, F.; Calcaterra, A.; Talamo, M. Newly Developed Nano-Calcium Carbonate and Nano-Calcium Propanoate for the Deacidification of Library and Archival Materials. J. Anal. Methods Chem. 2017, 2017, 1-8. [CrossRef]

10. Xu, Y.; Ye, J.; Zhou, D.; Su, L. Research progress on applications of calcium derived from marine organisms. Sci. Rep. 2020, 10, 18425. [CrossRef]

11. Al Omari, M.M.H.; Rashid, I.S.; Qinna, N.A.; Jaber, A.M.; Badwan, A.A. Chapter Two-Calcium Carbonate. In Profiles of Drug Substances, Excipients and Related Methodology; Brittain, H.G., Ed.; Academic Press: Cambridge, MA, USA, 2016; Volume 41, pp. 31-132.

12. Hussein, A.I.; Ab-Ghani, Z.; Che Mat, A.N.; Ab Ghani, N.A.; Husein, A.; Ab Rahman, I. Synthesis and Characterization of Spherical Calcium Carbonate Nanoparticles Derived from Cockle Shells. Appl. Sci. 2020, 10, 7170. [CrossRef]

13. Mydin, R.B.S.; Zahidi, I.N.M.; Ishak, N.N.; Shaida, N.; Ghazali, S.N.; Moshawih, S.; Siddiquee, S. Potential of Calcium Carbonate Nanoparticles for Therapeutic Applications. Malays. J. Med. Health Sci. 2018, 14, 2636-9346.

14. Bewernitz, M.A.; Lovett, A.C.; Gower, L.B. Liquid-Solid Core-Shell Microcapsules of Calcium Carbonate Coated Emulsions and Liposomes. Appl. Sci. 2020, 10, 8551. [CrossRef]

15. Palacios, S.; Ramirez, M.; Lilue, M. Clinical study of the tolerability of calcium carbonate-casein microcapsules as a dietary supplement in a group of postmenopausal women. Drugs Context 2020, 9, 2020-1-4. [CrossRef]

16. Rötzer, N.; Schmidt, M. Historical, Current, and Future Energy Demand from Global Copper Production and Its Impact on Climate Change. Resources 2020, 9, 44. [CrossRef]

17. Jannah, Z.; Mubarok, H.; Syamsiyah, F.; H Putri, A.A.; Rohmawati, L. Preparation of Calcium Carbonate (from Shellfish)/Magnesium Oxide Composites as an Antibacterial Agent. Iop Conf. Ser. Mater. Sci. Eng. 2018, 367, 012005. [CrossRef]

18. Islam, K.N.; Bakar, M.Z.B.A.; Ali, M.E.; Hussein, M.Z.B.; Noordin, M.M.; Loqman, M.Y.; Miah, G.; Wahid, H.; Hashim, U. A novel method for the synthesis of calcium carbonate (aragonite) nanoparticles from cockle shells. Powder Technol. 2013, 235, 70-75. [CrossRef]

19. Tangboriboon, N.; Kunanuruksapong, R.; Sirivat, A. Preparation and properties of calcium oxide from eggshells via calcination. Mater. Sci. Pol. 2012, 30, 313-322. [CrossRef]

20. Singh, M.; Kumar, S.V.; Waghmare, S.; Sabale, P.D. Aragonite-vaterite-calcite: Polymorphs of CaCO3 in 7th century, C.E lime plasters of Alampur group of Temples, India. Constr. Build. Mater. 2016, 112, 386-387. [CrossRef]

21. Habte, L.; Khan, M.D.; Shiferaw, N.; Farooq, A.; Lee, M.-h.; Jung, S.-h.; Ahn, J.W. Synthesis, Characterization and Mechanism Study of Green Aragonite Crystals from Waste Biomaterials as Calcium Supplement. Sustainability 2020, 12, 5062. [CrossRef]

22. Trushina, D.B.; Bukreeva, T.V.; Kovalchuk, M.V.; Antipina, M.N. $\mathrm{CaCO}_{3}$ vaterite microparticles for biomedical and personal care applications. Mater. Sci. Eng. C 2014, 45, 644-658. [CrossRef]

23. Nurul Islam, K.; Abu Bakar, M.Z.; Ali, M.; Hussein, M.; Noordin, M.M.; Yusof, L.; Haron, A.W.; Hakim, M.; Bee Abd Hamid, S. Facile Synthesis of Calcium Carbonate Nanoparticles from Cockle Shells. J. Nanomater. 2012, 2012, 5. [CrossRef]

24. Cabral Pinto, M.M.S.; Silva, M.M.V.G.; Neiva, A.M.R. Geochemistry of U-bearing minerals from the Vale de Abrutiga uranium mine area, Central Portugal. Neues Jahrb. Für Mineral. Abh. 2008, 185, 183-198. [CrossRef]

25. Cabral Pinto, M.M.S.; Silva, M.M.V.G.; Neiva, A.M.R.; Guimarães, F.; Silva, P.B. Release, Migration, Sorption, and (Re)Precipitation of U during Peraluminous Granite Alteration under Oxidizing Conditions in Central Portugal. Geosciences 2018, 8, 95. [CrossRef]

26. Cabral Pinto, M.; Silva, M.; Neiva, A.; Guimarães, F.; Silva, P. Uranium minerals from a Portuguese Variscan Peraluminous granite, its alteration and related uranium-quartz veins. In Uranium: Compounds, Isotopes and Applications; Wolfe, G., Ed.; Nova Science Publishers, Inc.: Hauppauge, NY, USA, 2009; pp. 287-318.

27. Idrees, H.; Zaidi, S.Z.J.; Sabir, A.; Khan, R.U.; Zhang, X.; Hassan, S.U. A Review of Biodegradable Natural Polymer-Based Nanoparticles for Drug Delivery Applications. Nanomaterials 2020, 10, 1970. [CrossRef] [PubMed]

28. Luo, X.; Song, X.; Cao, Y.; Song, L.; Bu, X. Investigation of calcium carbonate synthesized by steamed ammonia liquid waste without use of additives. Rsc Adv. 2020, 10, 7976-7986. [CrossRef]

29. Ranjan, R.; Narnaware, S.D.; Patil, N.V. A Novel Technique for Synthesis of Calcium Carbonate Nanoparticles. Natl. Acad. Sci. Lett. 2018, 41, 403-406. [CrossRef]

30. El-sherbiny, S.; El-Sheikh, S.; Barhoum, A. Preparation and modification of nano calcium carbonate filler from waste marble dust and commercial limestone for papermaking wet end application. Powder Technol. 2015, 279, 290-300. [CrossRef]

31. de Beer, M.; Maree, J.P.; Liebenberg, L.; Doucet, F. Conversion of calcium sulphide to calcium carbonate during the process of recovery of elemental sulphur from gypsum waste. Waste Manag. 2014, 34, 2373-2381. [CrossRef]

32. Yoada, R.M.; Chirawurah, D.; Adongo, P.B. Domestic waste disposal practice and perceptions of private sector waste management in urban Accra. Bmc Public Health 2014, 14, 697. [CrossRef]

33. Yadav, V.K.; Yadav, K.K.; Gnanamoorthy, G.; Choudhary, N.; Khan, S.H.; Gupta, N.; Kamyab, H.; Bach, Q.-V. A novel synthesis and characterization of polyhedral shaped amorphous iron oxide nanoparticles from incense sticks ash waste. Environ. Technol. Innov. 2020, 20, 101089. [CrossRef] 
34. Yadav, V.K.; Choudhary, N.; Heena Khan, S.; Khayal, A.; Ravi, R.K.; Kumar, P.; Modi, S.; Gnanamoorthy, G. Incense and Incense Sticks: Types, Components, Origin and Their Religious Beliefs and Importance among Different Religions. J. Bio Innov. 2020, 9, 1420-1439. [CrossRef]

35. Lin, T.-C.; Krishnaswamy, G.; S Chi, D. Incense smoke: Clinical, structural and molecular effects on airway disease. Clin. Mol. Allergy Cma 2008, 6. [CrossRef]

36. Yadav, V.K.; Singh, B.; Choudhary, N. Characterization of Indian Incense Stick Powders for their Physical, Chemical and Mineralogical Properties. World J. Environ. Biosci. 2020, 9, 39-43.

37. Abdel-Shafy, H.; Mohamed-Mansour, M. A review on polycyclic aromatic hydrocarbons: Source, environmental impact, effect on human health and remediation. Egypt. J. Pet. 2016, 25, 107-123. [CrossRef]

38. Yadav, V.K.; Gnanamoorthy, G.; Cabral-Pinto, M.M.S.; Alam, J.; Ahamed, M.; Gupta, N.; Singh, B.; Choudhary, N.; Inwati, G.K.; Yadav, K.K. Variations and similarities in structural, chemical, and elemental properties on the ashes derived from the coal due to their combustion in open and controlled manner. Environ. Sci. Pollut. Res. 2021. [CrossRef] [PubMed]

39. Oral, Ç.M.; Ercan, B. Influence of $\mathrm{pH}$ on morphology, size and polymorph of room temperature synthesized calcium carbonate particles. Powder Technol. 2018, 339, 781-788. [CrossRef]

40. Brandelli, A.; Sala, L.; Kalil, S.J. Microbial enzymes for bioconversion of poultry waste into added-value products. Food Res. Int. 2015, 73, 3-12. [CrossRef]

41. Faridi, H.; Arabhosseini, A. Application of eggshell wastes as valuable and utilizable products: A review. Res. Agric. Eng. 2018, 64, 104-114. [CrossRef]

42. M King'ori, A. A Review of the Uses of Poultry Eggshells and Shell Membranes. Int. J. Poult. Sci. 2011, 10, 908-912. [CrossRef]

43. Zaheer, K. An Updated Review on Chicken Eggs: Production, Consumption, Management Aspects and Nutritional Benefits to Human Health. Food Nutr. Sci. 2015, 06, 1208-1220. [CrossRef]

44. Nagamalli, H.; Sitaraman, M.; Kandalai, K.K.; Mudhole, G.R. Chicken egg shell as a potential substrate for production of alkaline protease by Bacillus altitudinis GVC11 and its applications. 3 Biotech 2017, 7, 185. [CrossRef] [PubMed]

45. Toro, P.; Abarca, R.; Yazdani-Pedram, M.; Luis Arias, J. Eggshell, a new bio-filler for polypropylene composites. Mater. Lett. 2007, 61, 4347-4350. [CrossRef]

46. Padhi, M.K. Importance of Indigenous Breeds of Chicken for Rural Economy and Their Improvements for Higher Production Performance. Scientifica 2016, 2016, 9. [CrossRef] [PubMed]

47. Glatz, P.; Zhihong, M.; Belinda, R. Handling and Treatment of Poultry Hatchery Waste: A Review. Sustainability 2011, 3, $216-237$. [CrossRef]

48. Hassan, T.; Rangari, V.; Rana, R.; Jeelani, S. Sonochemical effect on size reduction of $\mathrm{CaCO}_{3}$ nanoparticles derived from waste eggshells. Ultrason. Sonochemistry 2013, 20, 1308-1315. [CrossRef]

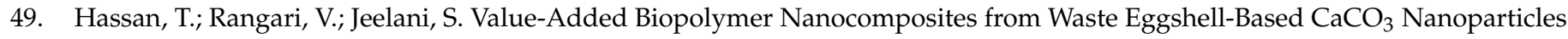
as Fillers. Acs Sustain. Chem. Eng. 2014, 2, 706-717. [CrossRef]

50. Hariharan, M.; Varghese, N.; Cherian, A.B.; Paul, J.; Antony, K.A. Synthesis and Characterisation of CaCO3 (Calcite) Nano particles from cockle shells Using Chitosan as Precursor. Int. J. Sci. Res. Publ. 2014, 4, 5.

51. Muhammad Mailafiya, M.; Abubakar, K.; Danmaigoro, A.; Musa Chiroma, S.; Bin Abdul Rahim, E.; Aris Mohd Moklas, M.; Abu Bakar Zakaria, Z. Cockle Shell-Derived Calcium Carbonate (Aragonite) Nanoparticles: A Dynamite to Nanomedicine. Appl. Sci. 2019, 9, 2897. [CrossRef]

52. Render, D.; Samuel, T.; King, H.; Vig, M.; Jeelani, S.; Babu, R.J.; Rangari, V. Biomaterial-Derived Calcium Carbonate Nanoparticles for Enteric Drug Delivery. J. Nanomater. 2016, 2016, 1-8. [CrossRef] [PubMed]

53. Pandita, P.; Fulekar, M.H. Egg shell waste as heterogeneous nanocatalyst for biodiesel production: Optimized by response surface methodology. J. Environ. Manag. 2017, 198, 319-329. [CrossRef]

54. Ahmad, S.; Chaudhary, S.; Pathak, V.V.; Kothari, R.; Tyagi, V.V. Optimization of direct transesterification of Chlorella pyrenoidosa catalyzed by waste egg shell based heterogenous nano-CaO catalyst. Renew. Energy 2020, 160, 86-97. [CrossRef]

55. Menon, V.; Gopakumar, K. Shellfish: Nutritive Value, Health Benefits, and Consumer Safety. Compr. Rev. Food Sci. Food Saf. 2017, 16, 1219-1242. [CrossRef]

56. Tamburini, E.; Turolla, E.; Fano, E.A.; Castaldelli, G. Sustainability of Mussel (Mytilus Galloprovincialis) Farming in the Po River Delta, Northern Italy, Based on a Life Cycle Assessment Approach. Sustainability 2020, 12, 3814. [CrossRef]

57. Hamester, M.R.R.; Balzer, P.S.; Becker, D. Characterization of calcium carbonate obtained from oyster and mussel shells and incorporation in polypropylene. Mater. Res. 2012, 15, 204-208. [CrossRef]

58. Joseph, A.M.; Snellings, R.; Van den Heede, P.; Matthys, S.; De Belie, N. The Use of Municipal Solid Waste Incineration Ash in Various Building Materials: A Belgian Point of View. Materials 2018, 11, 141. [CrossRef]

59. Cabral Pinto, M.M.S.; Ferreira da Silva, E.A. Heavy Metals of Santiago Island (Cape Verde) Alluvial Deposits: Baseline Value Maps and Human Health Risk Assessment. Int. J. Environ. Res. Public Health 2019, 16, 2. [CrossRef] [PubMed]

60. Cabral-Pinto, M.M.S.; Inácio, M.; Neves, O.; Almeida, A.A.; Pinto, E.; Oliveiros, B.; Ferreira da Silva, E.A. Human Health Risk Assessment Due to Agricultural Activities and Crop Consumption in the Surroundings of an Industrial Area. Expo. Health 2020, 12, 629-640. [CrossRef]

61. Gurbuz, A.; Sari, Y.; Yuksekdag, Z.; Cinar, B. Cementation in a matrix of loose sandy soil using biological treatment method. Afr. J. Biotechnol. 2011, 10, 7432-7440. 
62. Ferronato, N.; Torretta, V. Waste Mismanagement in Developing Countries: A Review of Global Issues. Int. J. Environ. Res. Public Health 2019, 16, 1060. [CrossRef]

63. Cabral Pinto, M.M.S.; Marinho-Reis, P.; Almeida, A.; Pinto, E.; Neves, O.; Inácio, M.; Gerardo, B.; Freitas, S.; Simões, M.R.; Dinis, P.A.; et al. Links between Cognitive Status and Trace Element Levels in Hair for an Environmentally Exposed Population: A Case Study in the Surroundings of the Estarreja Industrial Area. Int. J. Environ. Res. Public Health 2019, 16, 4560. [CrossRef]

64. Puyol, D.; Batstone, D.J.; Hülsen, T.; Astals, S.; Peces, M.; Krömer, J.O. Resource Recovery from Wastewater by Biological Technologies: Opportunities, Challenges, and Prospects. Front. Microbiol. 2017, 7, 2106. [CrossRef]

65. Maree, J.P.; Zvinowanda, C.M.; Mujuru, M.; Matsapola, R.M.; Delport, D.J.; Louw, a.W.J. Recovery of Calcium Carbonate from Wastewater Treatment Sludge Using a Flotation Technique. Chem. Eng. Process Technol. 2012, 3, 6. [CrossRef]

66. Xu, J.; Yan, C.; Zhang, F.; Konishi, H.; Xu, H.; Teng, H.H. Testing the cation-hydration effect on the crystallization of Ca-Mg-CO3 systems. Proc. Natl. Acad. Sci. USA 2013, 110, 17750-17755. [CrossRef] [PubMed]

67. Wonyen, D.; Kromah, V.; Gibson, B.; Nah, S.; Chelgani, S. A Review of Flotation Separation of Mg Carbonates (Dolomite and Magnesite). Minerals 2018, 8, 354. [CrossRef]

68. Yildirim, M.; Akarsu, H. Preparation of magnesium oxide (MgO) from dolomite by leach-precipitation-pyrohydrolysis process. Phys. Probl. Min. Process. 2009, 44, 15.

69. Somarathne, Y.R.; Mantilaka, P.; Karunaratne, D.G.G.P.; Rajapakse, R.; Pitawala, H.M.T.G.; Wijayantha, K. Synthesis of high purity calcium carbonate micro- and nano-structures on polyethylene glycol templates using dolomite. Cryst. Res. Technol. 2016, 51, 207-214. [CrossRef]

70. Mulopo, L.; Radebe, V. Recovery of calcium carbonate from waste gypsum and utilization for remediation of acid mine drainage from coal mines. Water Sci. Technol. 2012, 66, 1296-1300. [CrossRef] [PubMed]

71. Sultan, Z.; Sheikh, Z.; Zafar, M.S.; Sauro, S. Dental Materials (Principles and Applications); Paramount Book Publishers: Karachi, Pakistan, 2018.

72. Ko, J.H.; Xu, Q.; Jang, Y.-C. Emissions and Control of Hydrogen Sulfide at Landfills: A Review. Crit. Rev. Environ. Sci. Technol. 2015, 45, 2043-2083. [CrossRef]

73. Xu, Q.; Townsend, T.; Bitton, G. Inhibition of hydrogen sulfide generation from disposed gypsum drywall using chemical inhibitors. J. Hazard. Mater. 2011, 191, 204-211. [CrossRef]

74. Sufang, W.; Lan, P. Method for Preparing a Nano-Calcium Carbonate Slurry from Waste Gypsum as Calcium Source, the Product and Use thereof. US8846562B2, 31 October 2013.

75. Huber, M.; Stark, W.; Loher, S.; Maciejewski, M.; Krumeich, F.; Baiker, A. Flame synthesis of calcium carbonate nanoparticles. Chem. Commun. 2005, 648-650. [CrossRef] [PubMed]

76. Oyetunji, A.; Umunakwe, R.; Omotayo Adewuyi, B.; Samuel Nwigwe, U.; Janefrances Umunakwe, I. Evaluating the properties of nanoparticles of calcium carbonate obtained from the shells of african giant land snails (Achatina achatina) via in situ deposition technique. Upb Sci. Bull. Ser. B: Chem. Mater. Sci. 2019, 81, 86-94.

77. Chilakala, R.; Thenepalli, T.; Huh, J.-H.; Ahn, J.-W. Precipitated Calcium Carbonate Synthesis by Simultaneous Injection to Produce Nano Whisker Aragonite. J. Korean Ceram. Soc. 2016, 53, 222-226. [CrossRef]

78. Chilakala, R.; Thenepalli, T.; Huh, J.-H.; Ahn, J.-W. Preparation of Needle like Aragonite Precipitated Calcium Carbonate (PCC) from Dolomite by Carbonation Method. J. Korean Ceram. Soc. 2016, 53, 7-12. [CrossRef]

79. Zema, D.A.; Calabrò, P.S.; Folino, A.; Tamburino, V.; Zappia, G.; Zimbone, S.M. Valorisation of citrus processing waste: A review. Waste Manag. 2018, 80, 252-273. [CrossRef]

80. Mahato, N.; Sinha, M.; Sharma, K.; Koteswararao, R.; Cho, M.H. Modern Extraction and Purification Techniques for Obtaining High Purity Food-Grade Bioactive Compounds and Value-Added Co-Products from Citrus Wastes. Foods 2019, 8, 523. [CrossRef] [PubMed]

81. Khan, S.A.; Ahmad, R.; Asad, S.; Muhammad, S. Citrus flavonoids: Their biosynthesis, functions and genetic improvement. In Citrus Molecular Phylogeny, Antioxidant Properties and Medicinal Uses, 1st ed.; Hayat, K., Ed.; Nova Science Publishers: New York, NY, USA, 2014; pp. 31-51.

82. Kasana, R.C.; Panwar, N.R.; Kaul, R.K.; Kumar, P. Biosynthesis and effects of copper nanoparticles on plants. Environ. Chem. Lett. 2017, 15, 233-240. [CrossRef]

83. Gong, R.; Ye, J.; Dai, W.; Yan, X.; Hu, J.; Hu, X.; Li, S.; Huang, H. Adsorptive Removal of Methyl Orange and Methylene Blue from Aqueous Solution with Finger-Citron-Residue-Based Activated Carbon. Ind. Eng. Chem. Res. 2013, 52, 14297-14303. [CrossRef]

84. Mihara, N.; Soya, K.; Kuchar, D.; Fukuta, T.; Matsuda, H. Utilization of calcium sulfide derived from waste gypsum board for metal-containing wastewater treatment. Glob. Nest J. 2008, 10, 101-107.

85. Brooks, M.W.; Lynn, S. Recovery of Calcium Carbonate and Hydrogen Sulfide from Waste Calcium Sulfide. Ind. Eng. Chem. Res. Ind Eng Chem Res 1997, 36, 4236-4242. [CrossRef]

86. Chen, Q.; Ding, W.; Peng, T.; Sun, H. Synthesis and characterization of calcium carbonate whisker from yellow phosphorus slag. Open Chem. 2020, 18, 347-356. [CrossRef]

87. Abdolmohammadi, S.; Siyamak, S.; Ibrahim, N.A.; Yunus, W.M.Z.W.; Rahman, M.Z.A.; Azizi, S.; Fatehi, A. Enhancement of Mechanical and Thermal Properties of Polycaprolactone/Chitosan Blend by Calcium Carbonate Nanoparticles. Int. J. Mol. Sci. 2012, 13, 4508-4522. [CrossRef] [PubMed] 
88. Wan, C.; Wang, L.-T.; Sha, J.-Y.; Ge, H.-H. Effect of Carbon Nanoparticles on the Crystallization of Calcium Carbonate in Aqueous Solution. Nanomaterials 2019, 9, 179. [CrossRef]

89. Yadav, V.K.; Choudhary, N.; Khan, S.H.; Malik, P.; Inwati, G.K.; Suriyaprabha, R.; Ravi, R.K. Synthesis and Characterisation of Nano-Biosorbents and Their Applications for Waste Water Treatment. In Handbook of Research on Emerging Developments and Environmental Impacts of Ecological Chemistry; Gheorghe Duca, A.V., Ed.; IGI Global: Hershey, PA, USA, 2020; pp. $252-290$. [CrossRef]

90. Han, S.-J.; Yoo, M.; Kim, D.-W.; Wee, J.-H. Carbon Dioxide Capture Using Calcium Hydroxide Aqueous Solution as the Absorbent. Energy Fuels 2011, 25, 3825-3834. [CrossRef]

91. Hong, K.-S.; Myoung Lee, H.; Seong Bae, J.; Gyu Ha, M.; Sung Jin, J.; Hong, T.E.; Pil Kim, J.; Jeong, E. Removal of Heavy Metal Ions by using Calcium Carbonate Extracted from Starfish Treated by Protease and Amylase. J. Anal. Sci. Technol. 2011, 2, 75-82. [CrossRef]

92. Park, H.; Wook Jeong, S.; Yang, J.-K.; Gil Kim, B.; Lee, S.-M. Removal of Heavy Metals Using Waste Eggshell. J. Environ. Sci. (China) 2007, 19, 1436-1441. [CrossRef]

93. Liu, Y.; Jiang, Y.; Hu, M.; Li, S.; Zhai, Q.-G. Removal of triphenylmethane dyes by calcium carbonate-lentinan hierarchical mesoporous hybrid materials. Chem. Eng. J. 2015, 273, 371-380. [CrossRef]

94. Yadav, V.K.; Fulekar, M.H. Biogenic synthesis of maghemite nanoparticles ( $\gamma$-Fe2O3) using Tridax leaf extract and its application for removal of fly ash heavy metals (Pb, Cd). Mater. Today Proc. 2018, 5, 20704-20710. [CrossRef]

95. Sales da Silva, I.G.; Gomes de Almeida, F.C.; Padilha da Rocha e Silva, N.M.; Casazza, A.A.; Converti, A.; Asfora Sarubbo, L. Soil Bioremediation: Overview of Technologies and Trends. Energies 2020, 13, 4664. [CrossRef]

96. Singh, R.; Behera, M.; Kumar, S. Nano-bioremediation: An Innovative Remediation Technology for Treatment and Management of Contaminated Sites. In Bioremediation of Industrial Waste for Environmental Safety; Bharagava, R., Ed.; Springer: Singapore, 2020; pp. 165-182. [CrossRef]

97. Mohammadifard, H.; Amiri, M.C. On tailored synthesis of nano CaCO3 particles in a colloidal gas aphron system and evaluating their performance with response surface methodology for heavy metals removal from aqueous solutions. J. Water Environ. Nanotechnol. 2018, 3, 141-149. [CrossRef]

98. Jacob, J.; Varalakshmi, R.; Gargi, S.A.; Jayasri, M.; Suthindhiran, K. Removal of Cr (III) and Ni (II) from tannery effluent using calcium carbonate coated bacterial magnetosomes. Npj Clean Water 2018, 1. [CrossRef]

99. Abeykoon, K.G.M.D.; Dunuweera, S.P.; Rajapakse, R.M.G. Synthesis of porous cakcium carbonate nanoparticles and isotherm studies for the removal of flouride in different water sources as a solution for CKD. In Proceedings of the 4th International Conference on Nanoscience and Nanotechnology 2017(ICNSNT 2017), Colombo, Sri Lanka, 14-15 December 2017 ; p. 1.

100. Shan, D.; Wang, Y.; Xue, H.; Cosnier, S. Sensitive and selective xanthin amperometric sensors based on calcium carbonate nanoparticles. Sens. Actuators B Chem. 2009, 136, 510-515. [CrossRef]

101. Gul, I.; Ahmad, M.S.; Naqvi, S.S.; Hussain, A.; Wali, R.; Farooqi, A.A.; Ahmed, I. Polyphenol oxidase (PPO) based biosensors for detection of phenolic compounds: A Review. J. Appl. Biol. Biotechnol. 2017, 5, 13. [CrossRef]

102. Mosleh, M. Application of new method for the synthesis of cobalt tungstate nanostructures and cobalt tungstate/calcium carbonate nanocomposites and removal of organic pollutants. J. Mater. Sci. Mater. Electron. 2018, 29, 4855-4861. [CrossRef] 